\title{
Stakeholder Management-One of the Clues of Sustainable Project Management-As an Underestimated Factor of Project Success in Small Construction Companies
}

\author{
Agata Klaus-Rosińska *(D) and Joanna Iwko (D) \\ Faculty of Computer Science and Management, Wroclaw University of Science and Technology, \\ 50-370 Wroclaw, Poland; joanna.iwko@pwr.edu.pl \\ * Correspondence: agata.klaus-rosinska@pwr.edu.pl
}

Citation: Klaus-Rosińska, A.; Iwko, J. Stakeholder Management-One of the Clues of Sustainable Project Management-As an Underestimated Factor of Project Success in Small Construction Companies.

Sustainability 2021, 13, 9877. https:// doi.org/10.3390/su13179877

Academic Editor: António Abreu

Received: 30 July 2021

Accepted: 28 August 2021

Published: 2 September 2021

Publisher's Note: MDPI stays neutral with regard to jurisdictional claims in published maps and institutional affiliations.

Copyright: (c) 2021 by the authors. Licensee MDPI, Basel, Switzerland. This article is an open access article distributed under the terms and conditions of the Creative Commons Attribution (CC BY) license (https:/ / creativecommons.org/licenses/by/ $4.0 /)$.

\begin{abstract}
According to contemporary literature, stakeholder management (which is one of the identified clues of sustainable project management) plays a significant role in successfully delivering construction projects. However, the literature focuses on the issues of stakeholder management/analysis mainly for large projects, and the authors could not find any items related to small construction projects. The aim of the article is to present the results of research conducted in small construction companies in the context of stakeholder management of their projects against the background of project success and sustainability. Many researchers have concluded that stakeholder management is one of the success factors of projects (including construction projects). Based on the conducted quantitative research, the needs in the field of stakeholder management of small construction companies' projects were determined and the approaches used in this area were diagnosed. The research results indicate a low level of maturity of small construction companies in managing project stakeholders, which is a surprising result considering the fact that the literature on the subject emphasizes the importance of taking care of the project stakeholder management area and associating it with the project's success.
\end{abstract}

Keywords: sustainable project management; project stakeholders management; project success; construction companies

\section{Introduction}

Projects and their management are recognized as a way to sustainability [1,2]. According to [3], it would be best for all stakeholders to demonstrate pro-environmental and pro-social attitudes. In such a case, the project contributes to sustainable development. At the same time, it is highlighted that it is not possible to achieve this ideal state, so it is necessary to focus on the stakeholders who are originators of the project, approve and finance it, and take part in its execution. Stakeholder management allows identification and analysis of those key project stakeholders and preparation of a strategy to manage them and the project team's activities in this regard. Because of these actions, the key project stakeholders' attitude will be developed, which can determine whether the project will contribute to sustainable development and be executed with its principles.

It is recognized that projects play an essential role in the realization of more sustainable business practices and the relationship between projects and sustainability is visible in the following examples: considering projects from a societal perspective, having management for stakeholders' approach, applying triple bottom line criteria, and taking a values-based approach to projects and project management. The integration of the concepts of sustainability into the processes, standards, and practices of project management is an emerging field of study and is constantly being developed [4]. There are several (9) dimensions of sustainability that are relevant to understanding the impact of sustainability 
on project management. One of them is "Sustainability is about stakeholder participation" [5]/"Sustainability is about stakeholder orientation" [6], which simply means that considering and respecting the potential interests of stakeholders is key to sustainability. Few literature items about this sustainable concept have focused specifically on project stakeholders, e.g., [7-9]. The research in this regard suggests that engaging stakeholders with all their interests in project management activities is desirable [10]. According to [4], in the published studies about sustainability in project management, the building/construction industry is well represented.

Generally, in the contemporary literature, stakeholder management/analysis is treated as one of the most important aspects of project management and emphasizes the importance of stakeholder participation in projects, e.g., [6,11,12]. According to [13], stakeholder management plays a significant role in successfully delivering construction projects. A similar view (also in the context of construction projects) can be found in $[14,15]$. The literature has focused on the issues of stakeholder management/analysis mainly for large projects, and the authors of this publication could not find any items related to small construction projects. This was considered as a research gap, which contributed to the originality of this paper. Additionally, the authors of [16] emphasize that the need for improvement in stakeholder management in construction projects still exists.

The aim of the article is to present the results of research conducted in small construction companies in the context of stakeholder management of their projects against the background of project success and sustainability. Many researchers have concluded that stakeholder management is considered as one of the success factors of projects (including construction projects). Based on the conducted quantitative research, the needs in the field of stakeholder management of small construction companies' projects were determined and the approaches used in this area were diagnosed.

The practical impact of this article was influenced by the results of the research carried out by the authors, which can be used by managers to manage stakeholders in small construction companies. The results are useful for improving the project maturity of this type of organization.

\section{Methodology}

The literature research conducted for this paper was a typical literature review, which covers a wide range of topics at different levels of comprehensiveness and may include analysis of research findings. The search method (search) in this type of literature research is as comprehensive as possible, the appraisal method (appraisal) is possible, the summary method (synthesis) is narrative, and the data analysis method (analysis) chronological, conceptual, and thematic [17].

The focus of this paper is on project stakeholder management in the context of the success factors of projects and one of the clues of sustainable management. For the purpose of conducting the literature and empirical research, 5 research questions were posted. The conducted research process (with research questions) is presented in Figure 1.

This study consists of three main parts. The first part of the article presents a conceptual framework based on 4 elements: (i) the first presents the concept of project success also taking into account the perspective of project stakeholders, (ii) the second explains the essence of success factors and ties that term to construction projects, (iii) the third presents the links between stakeholder management and the concept of sustainability, and (iv) the fourth describes the management of stakeholders in construction projects. The second part explains the methodology of the empirical research undertaken, describing the research sample, the data collection process, and the analysis of the results of the quantitative research. The third part ends the article with conclusions. 


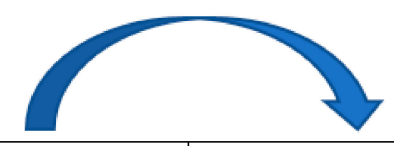

\begin{tabular}{|c|c|c|}
\hline & $\begin{array}{l}\text { Step I. Literature research - } \\
\text { literature review type }\end{array}$ & $\begin{array}{l}\text { Step II. Empirical research - } \\
\text { quantitative research }\end{array}$ \\
\hline Research question (1) & $\begin{array}{l}\text { What is project success and does it } \\
\text { include the perspective of project } \\
\text { stakeholders in its definition? }\end{array}$ & \\
\hline Research question (2) & $\begin{array}{l}\text { Is stakeholder management } \\
\text { (stakeholder analysis) considered } \\
\text { as one of the success factors of } \\
\text { projects? }\end{array}$ & \\
\hline Research question (3) & $\begin{array}{l}\text { Is stakeholder management } \\
\text { (stakeholder analysis) related to } \\
\text { sustainability concept? }\end{array}$ & \\
\hline Research question (4) & \multicolumn{2}{|c|}{ Are stakeholders managed (analyzed) in construction projects? } \\
\hline Research question (5) & & $\begin{array}{l}\text { How are project stakeholders } \\
\text { managed in small construction } \\
\text { companies? }\end{array}$ \\
\hline
\end{tabular}

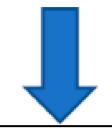

\section{Step III. Results, Discussion and Conclusions}

Figure 1. Research process conducted for the article needs. Source: own work.

\section{Literature Review and Theoretical Background}

Literature research was conducted in the Scopus database. The literature was reviewed according to the different search phrases from Table 1.

Table 1. The literature review characteristics.

\begin{tabular}{|c|c|c|c|c|c|}
\hline ID & Search Phrases & Limitations & $\begin{array}{l}\text { Results } \\
\text { Found }\end{array}$ & $\begin{array}{l}\text { Results after Pre-Selection } \\
\text { (Pre-Selection Was about } \\
\text { Analysis of the Titles) }\end{array}$ & $\begin{array}{c}\text { Results Reviewed } \\
\text { (After Analysis of } \\
\text { the Abstracts) }\end{array}$ \\
\hline 1. & project success & $\begin{array}{l}\text { 1. Year: 2020, } 2021 \\
\text { 2. Document type: Article, Conference } \\
\text { Paper, Book Chapter, Book } \\
\text { 3. Subject area: Business, } \\
\text { Management and Accounting } \\
\text { 4. Keyword: Project Management }\end{array}$ & 581 & 30 & 7 \\
\hline 2. & $\begin{array}{l}\text { critical success } \\
\text { factors and } \\
\text { construction projects }\end{array}$ & $\begin{array}{l}\text { 1. Document type: Article, Conference } \\
\text { Paper, Book Chapter, Book } \\
\text { 2. Subject area: Business, } \\
\text { Management and Accounting } \\
\text { 3. Keyword: Project Management }\end{array}$ & 154 & 42 & 22 \\
\hline 3. & $\begin{array}{l}\text { sustainability in } \\
\text { project management }\end{array}$ & $\begin{array}{l}\text { 1. Document type: Article, Conference } \\
\text { Paper, Book Chapter, Book }\end{array}$ & 40 & 32 & 11 \\
\hline 4. & $\begin{array}{c}\text { stakeholders } \\
\text { management and } \\
\text { construction projects }\end{array}$ & $\begin{array}{l}\text { 1. Document type: Article, Conference } \\
\text { Paper, Book Chapter, Book } \\
\text { 2. Subject area: Business, } \\
\text { Management and Accounting } \\
\text { 3. Keyword: Project Management }\end{array}$ & 505 & 41 & 19 \\
\hline & & & \multicolumn{2}{|c|}{ Total (excluding repeats) } & 59 \\
\hline
\end{tabular}


In every case of searching, too many results were obtained and narrowing down of the criteria was needed. It is visible in the column limitations. One limitation should be commented on-in the ID1 search phrase-limitation 1: year 2020, 2021. The concept of project success was explored by one of the article's authors based on publications published up to 2019 [18], so it was decided not to repeat this action. Four different search results will be discussed separately, for better readability.

\section{1. (i) The Concept of Project Success Also Taking into Account the Perspective of Project Stakeholders}

The concept of "success" in the context of projects is defined differently. Many authors of publications on the topic distinguish the concept of project success from project management success. What is this difference? Project success should be measured by comparing project outcomes to project objectives, while project management success should be measured by traditional measures of project progress, such as cost, time, and quality [19-21]. Some authors prefer to consider the success of a project as the fulfilment of its objectives and the achievement of benefits thanks to it [22]. Success understood in this way can be measured at the end of the project [19]. Others define the term project management success [23] as an outcome that can be measured during the course of the project, e.g., by meeting the budget or schedule or achieving the required quality [19]. Many researchers [24-26] believe that success (in project management) includes two components: project success and project management success. It is worth presenting one definition of success: project success is the delivery of a product of maximum business value to the customer within the constraints of time and budget [27]. The cited definition also points to an additional aspect, namely that success will be determined by the evaluator [28]. Thus, success will be associated with satisfying the various stakeholders of the project [29,30], such as the customer, sponsor, or other interested stakeholders, and will be achieved by meeting pre-defined requirements for the project and the resulting deliverables [31]. Stakeholder expectations, however, may vary. The results published in [32] indicate that each stakeholder group in construction projects pursues expectations in line with the social, environmental, and economic sustainability objectives. For effective management, project managers must know stakeholders' opportunities and threats, fulfill social responsibilities, establish common goals, apply appropriate strategies, and enhance stakeholder satisfaction. The fact that project success should be considered from the perspective of different stakeholders has been noted by many researchers, including J.K. Pinto and D.P. Slevin, according to whom project success is not only about the project itself (i.e., the project manager and the project team), but also about the customer [23,33,34]. G.P. Prabhakar notes that in any organization, the success of a project is evaluated by various stakeholders, such as customers, employees, and managers [35]. According to the researchers who wrote [36], in construction projects, the client has the highest level of impact on the projects, followed by the project managers and senior management. On how success is perceived by various stakeholders, much research has been done by K. Davis [37-39]. She points out that in the literature, success is rarely evaluated from the perspective of different stakeholders and the focus is mainly on project managers' perceptions of success. Her literature research (on 29 source items) led to the identification of the main types of project stakeholders and revealed how they perceive (understand) success (see Table 2).

In conclusion, for a project to be successful, identifying its stakeholders, analyzing their expectations and concerns, and implementing a strategy to manage seem to be crucial. The research presented in [40] revealed that stakeholders (of the engineering, procurement, and construction management projects (EPCM)) should be effectively integrated in the organization management processes to improve project success. The authors of [41] emphasize the importance of the role of awareness in strengthening the relationship between stakeholder management and project success in the construction industry. The research presented revealed that stakeholder management positively impacts project success and also affirms the positive moderation of awareness. According to [42], understanding stakeholders' influence is essential to achieving success, especially the external stakeholders. 
This was also confirmed by [43]. Stakeholder management (analysis) is one of the success factors mentioned in the literature for construction projects.

Table 2. The project stakeholders and how their perceive success.

\begin{tabular}{|c|c|c|}
\hline & Project Stakeholder Type & Perception of Success by Project Stakeholder Type \\
\hline 1. & Project manager & $\begin{array}{l}\text { Project managers view project success mainly in terms of } \\
\text { the iron triangle (cost, time, and quality), but also customer satisfaction, } \\
\text { good relations within the project team, and implementation of the } \\
\text { project product. }\end{array}$ \\
\hline 2. & Project team & $\begin{array}{l}\text { The project team perceives project success through good collaboration } \\
\text { within the project, the importance of the project to the organization and/or the } \\
\text { environment, and accomplishment of the planned project work. }\end{array}$ \\
\hline 3. & Client, user & $\begin{array}{l}\text { The client perceives project success by the acceptance of their needs/requirements by } \\
\text { the project manager, the satisfaction of the end users with the products delivered by } \\
\text { the project, and efficient communication between them and the project. } \\
\text { The end user perceives the success of the project primarily through the satisfaction of } \\
\text { their needs through the products of the project. }\end{array}$ \\
\hline 4. & $\begin{array}{l}\text { Other stakeholders, such } \\
\text { as owner, sponsor }\end{array}$ & $\begin{array}{l}\text { In the case of other stakeholders, project success is considered in the context of } \\
\text { achieving their intended goals. } \\
\text { In the case of a sponsor, the success of a project is understood by his achievement of } \\
\text { the intended profits. } \\
\text { For the owner, if the project is external, success is viewed through the gains the } \\
\text { organization has made through the project. When the project is internal, the owner } \\
\text { also considers the involvement of the organization's employees in the project. }\end{array}$ \\
\hline
\end{tabular}

Source: own work.

\section{2. (ii) Project Success Factors and Their Links to Construction Projects}

In order to evaluate the success of a project, the definition of ways to measure it is required. In this section of the paper, the term success factors will be defined and its difference from the term success criteria will be explained. In the literature, many authors [19,44-47] suggest defining the two mentioned terms as follows:

- Success criteria are dimensions for evaluating whether a project has succeeded or failed. When evaluating success, they are the dependent variables. Success criteria should be established before success factors are identified [48,49];

- Success factors are independent variables, which, if they affect the project, increase the probability of its success. They are also referred to in the literature as critical success factors (CSFs) or determinants or measures of success.

In the construction project literature, the above-mentioned distinction is also used, e.g., in [50].

According to the literature, there is no one-size-fits-all list of success criteria for all types of projects [51]. The criteria for success will vary across projects depending on many aspects, including the size or complexity of the project [29,44]. Often, success criteria are associated with the iron triangle of a project, namely cost, time, and quality, as pointed out, for example, by Pinto and Slevin [52] and Chan et al. [53]. However, many researchers emphasize that even taking all of these criteria into account at once, evaluating the success of a project using them will be insufficient $[25,34,54]$. First of all, they do not take into account whether the project product met the needs of the end users [55]. Taking into account the earlier part of this article (i), which concludes that success may mean something different to different stakeholders, success criteria should comprehensively reflect different interests. There are many examples in the literature of this approach [56-59].

The same is true for project success factors. As success can be perceived differently, many researchers believe that a universal list of success factors cannot be identified, because it should be tailored to the appropriate context [45], e.g., the nature of the project (project type). On the other hand, the literature contains research that has established a general list 
of project success factors and the opinion that despite the projects' differences, a universal list of success factors can be established, e.g., [60]. A similar approach to the subject is taken by K. Fraczkowski, B. Gładysz, and D. Kuchta, who identified (based on their literature research) 43 potential types of success factors [61]. One of the types of project success factors is the type of stakeholder management.

There are an extensive number of factors that influence the success and failure of projects, but an inclusive categorization of them is lacking, especially in construction [62]. In the recent literature on the issue of project success (2020s, 2021s), the most frequently studied CSFs are those dedicated to IT projects, e.g., [63,64]. However, items that identify and categorize CSFs specifically for construction projects can be found (also in the years 2020, 2021) [13,65-83]. For instance, the authors of [82] state five major groups of success factors for construction projects: project-related factors, project procedures, project management actions, human-related factors, and the external environment. Similarly, the authors of [81] indicate groups but in different frames: effective procurement, project implementability, government guarantee, favorable economic conditions, and available financial market. The identified success factors for construction projects include the following, among others, : a strong and good private consortium; appropriate risk allocation; available financial market [81]; open and effective communication; clear and precise briefing documents; clear intention and objectives of client, and clear project goal and objectives [80]; project nature, effective project management action, and the adoption of innovative management approaches [79]; competence, commitment, communication, and cooperation [84]; clear and realistic project goals, project planning, the project manager's competence, relevant past experience of the project management team, the competence of the project management team, clear and precise goals/objectives of the client, the project's value, the project's complexity and uniqueness, the project manager's experience, and the client's ability to make timely decisions [75]; scope, contract-admin, human resources, and health safety [74]; and top management support, adequate funding, availability of resources, and effective strategic planning [73]. CSF for construction projects have rarely explicitly named stakeholder management/analysis, but they largely refer to this aspect (e.g., effective communication, cooperation, clear and precise goals/objectives of the client). However, one publication [13] explicitly examined the relationships among critical success factors for stakeholder management in construction. The results of the study showed that stakeholder engagement/empowerment has a direct positive impact on project success.

\section{3. (iii) Stakeholder Management and the Concept of Sustainability}

Sustainable business strategies are being implemented in many projects, which has led to a recent expansion of the interest in exploring the potential of integrating sustainability dimensions in project management [85]. Sustainability in project management is about social (people), environment (planet), and financial (economic) aspects/goals $[4,86]$. As mentioned before, stakeholders' involvement and participation in projects are significant for sustainability from the project's point of view (inclusion of a social aspect). The appropriate consideration for stakeholder's interest in projects supports bilateral communication in the project management and further leads to overall stakeholder management. Management should strive to involve, motivate, and promote the stakeholder's participation in their projects. The stakeholder's participation must reflect all project management procedures being performed [5,87]. Effective stakeholder involvement requires communication and the development of common agenda among all stakeholders. The stakeholders can identify the problematic area in the project and develop solutions to the identified problems. The stakeholders can implement solutions and further measure the progress of the projects [88]. Several authors [7,89-91] have recognized the need for more open and proactive engagement of stakeholders as a consequence of integrating sustainability into project management [4]. According to [92], proactive stakeholder engagement is one of the basic principles of sustainability $[6,87]$. 
The relationship between sustainable project management and project success has been addressed in several studies, e.g., [93-97], and a positive correlation between sustainable project management and project success has been identified $[98,99]$. We also found research on the key factors of sustainability in the project management context (including project stakeholder management) from the perspective of project managers [100] on whether research on key factors directly contributes towards sustainability's success in construction projects (including stakeholder engagement/management) [101]. In [91], it is shown that achieving sustainability-related targets in construction projects is increasingly becoming a key performance driver and there is a need for a systematic approach to engage stakeholders with high importance in relation to sustainability.

\section{4. (iv) Management of Stakeholders in Construction Projects}

Stakeholders are considered as one of the major pillars of construction projects and management of stakeholders is essential for effective project management in the construction industry [14]. Stakeholder management in construction projects is an essential process, which aims to maximize positive inputs and minimize unfavorable attitudes by taking into account the needs and requirements of all project stakeholders [15]. The authors of the [102] confirm that the skills and actions of internal stakeholders are vital to the stakeholder management process, show that the one-off stakeholder identification proposed in the literature is a defective approach, and propose that the identification of external stakeholders' interests should be dynamic. How are stakeholders managed in construction projects? The literature refers specifically to large construction projects (also named megaprojects, long-term complex megaconstruction (LCM) projects, mega construction projects (MCPs)). In [103], the authors claim that construction project teams have started to apply sophisticated methods to analyze stakeholders (like snowball rolling and the stakeholder attribute assessment method). However, project teams are still reluctant to use complicated tools that need specialists' assistance. This is confirmed by [104], who concluded that traditional stakeholder analysis techniques are widely adopted in MCP regardless of their weaknesses and indicated that a social network approach for managing stakeholder interrelationships in these projects is needed. Moreover, in [15], the authors suggest that current project stakeholder management mechanisms are reactive rather than proactive, mainly offering an instrumental perspective, which aims to make the stakeholders comply with project needs. The authors of [105] conclude that building information modelling (BIM) has huge potential for the management of stakeholders on construction projects, as BIM can help project teams to proactively satisfy stakeholders by engaging them early in the construction process and seek solutions that avoid or minimize delays and conflicts. On the other hand, the analysis performed in [106] shows that LCM projects require a stronger emphasis on responding to environmental changes and social cooperation. The results of the analysis along with the CSF priorities reveal the necessity of taking customized approaches to LCM projects.

Recommendations for stakeholder management of construction projects in general can also be found in the literature [36,107-112]. However, the authors did not note research findings on stakeholder management of small construction projects. This can be considered as a research gap. Additionally, many researchers believe that the topic of stakeholder management of construction projects has seldom been explored. The authors of [113] provide information about the past, current, and future stakeholder perspective studies in construction projects. It emphasizes a lack of detailed discussions on stakeholder engagement in sustainable urban projects, lack of generalization of stakeholder studies in complex construction projects, and limited application of dynamic and simulation stakeholder analysis in uncertain project environments. According to [16], the need for improvement in stakeholder management practices still exists.

The main conclusions from the theoretical part include the following points:

- A project's success will be associated with satisfying the various stakeholders of the project; 
- One of the types of project success factors is the type of stakeholder management;

- There are an extensive number of factors that influence the success and failure of projects, but an inclusive categorization of them is lacking, especially in construction;

- Single literature items that identify and categorize CSFs specifically for construction projects can be found;

- Stakeholder engagement/empowerment has a direct positive impact on project success;

- Management should strive to involve, motivate, and promote the stakeholder's participation in their projects;

- A positive correlation between sustainable project management and project success can be found;

- There is a need for a systematic approach to engage stakeholders with high importance in relation to sustainability; and

- No research findings on stakeholder management of small construction projects exist.

\section{Empirical Part}

\subsection{Data Collection}

Data were collected from companies in Poland that run construction projects. Construction projects provide a good starting point for examining the impact of project stakeholder management on project success. A typical construction project involves many stakeholders, including contracting partners (clients/sponsors), contractors, and supervisors. Contractors are responsible for the construction; clients focus on the quality, cost, and duration of the project; and the supervisor monitors the quality, cost, and duration during the entire construction cycle [114].

In total, 50 construction companies registered or operating in Poland from the Central Registration and Information on Businesses (CEIDG) database and the National Court Register (KRS) were selected for the study. The companies were selected on the basis of their area of activity according to the PKD code (Polish Classification of Activities) in general sections $\mathrm{F}$ "construction" in division 41 "construction of buildings", 42 "civil engineering", and 43 "specialized construction activities". The companies that met the assumed criterion were selected by drawing lots. The study was conducted in the form of a telephone interview. The estimated time of the study for one respondent was about $8 \mathrm{~min}$. The research was conducted in December 2020 on a sample of 50 construction companies.

The research procedure included obtaining consent from the respondent for the research and informing him about the anonymization of data processing. In the first part of the survey, the respondents answered the 6 introductory (demographics) questions, i.e., providing information on the number of employees, the value of annual revenues, conducting international cooperation, the method of delivering products/services to customers, the main owner of the company, and the date of commencement of operations. In the second part of the survey, the respondents answered the questions in the main part, including the respondent's attitude to each question related to stakeholder management to a verbal statement. The questionnaire was prepared in Polish, and the research was conducted in that language due to the fact that it concerned construction companies operating in Poland. For the purposes of this study, the questionnaire was translated into English by project management specialists. Respondents answered each question in the questionnaire using a seven-point Likert scale (ranging from 1 for "definitely no" through 2-"almost no", 3-“slightly", 4-“to a moderate extent", 5-“pretty much", 6-“basically yes" to 7-"definitely yes", and 8 for "hard to say"). The questionnaire questions are presented in Appendix A.

\subsection{General Information about the Research Sample}

In the research sample of 50 construction companies, $32(64 \%)$ were micro-enterprises (employ less than 9 employees), 15 (26\%) were small enterprises (employ between 10 and 49 employees), and $3(10 \%)$ were medium-sized enterprises (employ between 50 and 250 employees). In the research group, there were no large enterprises (employ over 
250 employees) (question Q16). In the area of international cooperation, 39 (78\%) of the companies replied that they operated only in Poland, $9(18 \%)$ of the companies conducted international activities in the European Union, $2 \%$ of the companies conducted international activities outside the EU, and $2 \%$ of the companies operated globally (question Q18). As many as $39(78 \%)$ of the companies operated on the market after 1990 while the remaining $11(22 \%)$ companies started operating before 1990 (question Q20). Among the respondents who took part in the survey, $26 \%$ were board members in the company, $4 \%$ were business area managing directors, $2 \%$ were project/program/portfolio managers, $2 \%$ were project office directors, and $66 \%$ of the respondents performed other functions in the organization than those listed in the metric (question Q21 (in question Q21, the following ranks were assigned: 1 -manager and below (21.9\%); 2 -director, vice-president, co-owner (18.8\%); 3 -owner (59.4\%))).

Figure 2 shows the characteristics of the research sample.

Questions Q16, Q18, Q20, and Q21 are hereinafter referred to as Demographics16 (the number of employees), Demographics18 (conducting international cooperation), Demographics20 (date of commencement of operations), and Demographics21 (respondent's function in the organization). When it comes to the annual revenue generated in the company, $98 \%$ of the companies generated annual revenue below PLN 40 million while $2 \%$ of the companies generated annual revenue between PLN 40 and 200 million. There were no enterprises in the research group that generated annual revenue in excess of PLN 400 million (question Q17). The main owner of $92 \%$ of the companies was a domestic investor, $4 \%$ of the companies was owned by a foreign investor, and $4 \%$ of the companies replied "different" (question Q19). Question Q17 (the value of annual revenues) and Q19 (the main owner of the company) from the metric were not considered in further analyses due to the fact that $98 \%$ of the respondents indicated that the value of annual revenue in their company was below PLN 40 million, and the main company's owner was a domestic investor.

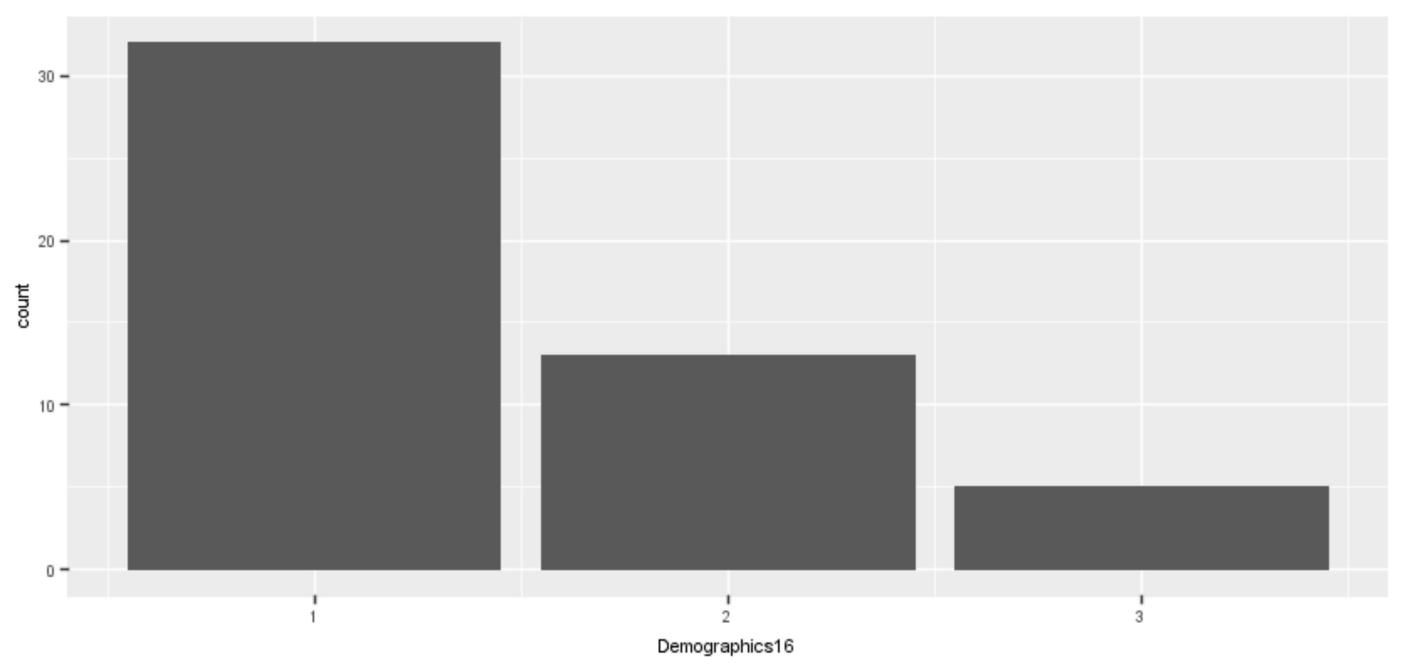

Figure 2. Cont. 

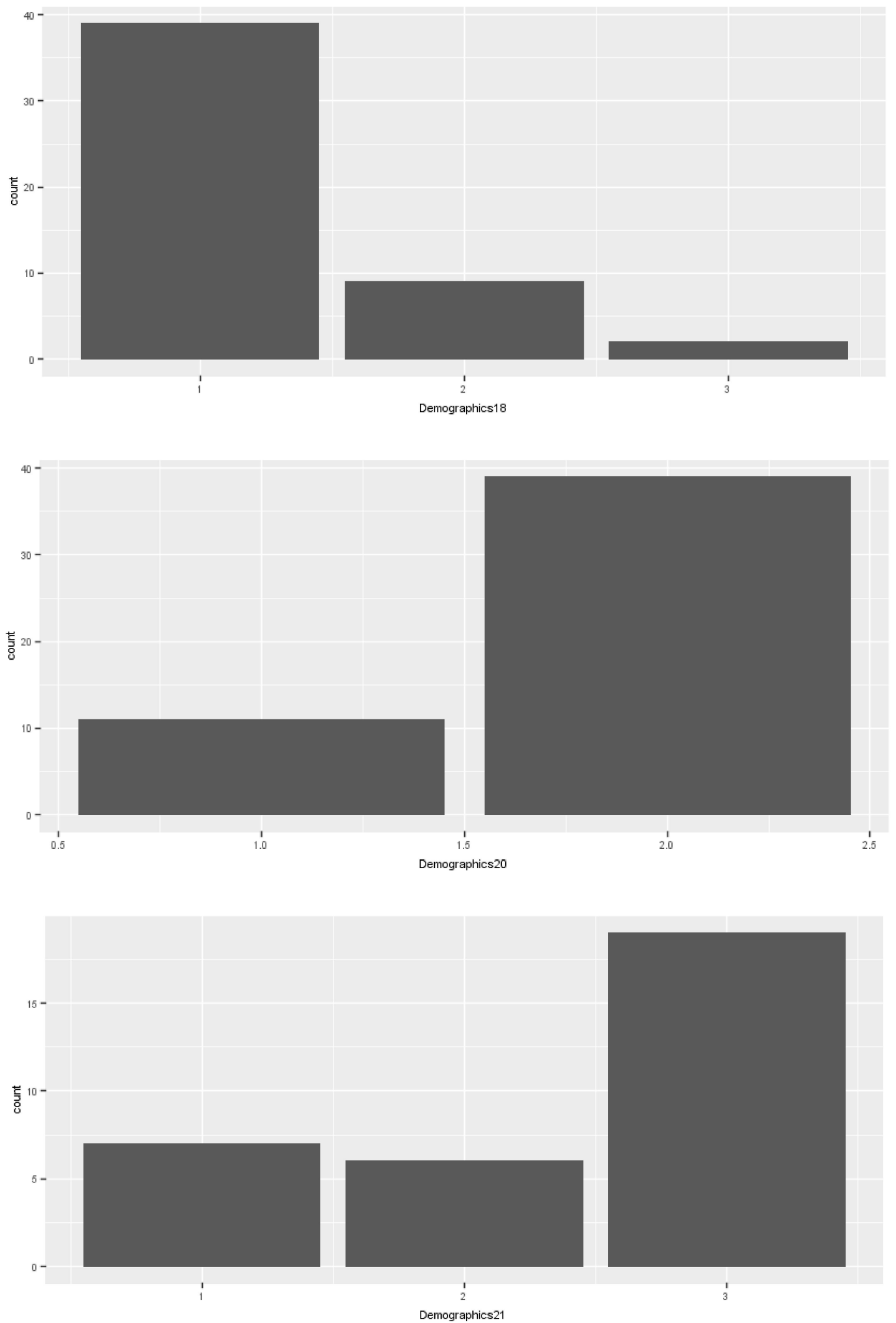

Figure 2. Characteristics of the research sample: Demographics16 (the number of employees), Demographics18 (conducting international cooperation), Demographics20 (date of commencement of operations), Demographics21 (respondent's function in the organization). Source: own work. 


\section{Results}

Figures 3-7 show the distribution of answers to questions Q1, Q12, Q13, Q14, and Q15 (see Appendix A). The $Y$-axis shows the number of respondents' indications for each answer. The $X$-axis shows a seven-point Likert scale (ranging from 1 for "definitely no", through 2-“almost no", 3-"slightly", 4-“"to a moderate extent", 5-“pretty much", 6-"basically yes" to 7-“definitely yes") (in questions (Q1, Q12, Q13, Q14, Q15), the number 8 answer ("hard to say") was removed, because it was used as an "undecided" question).

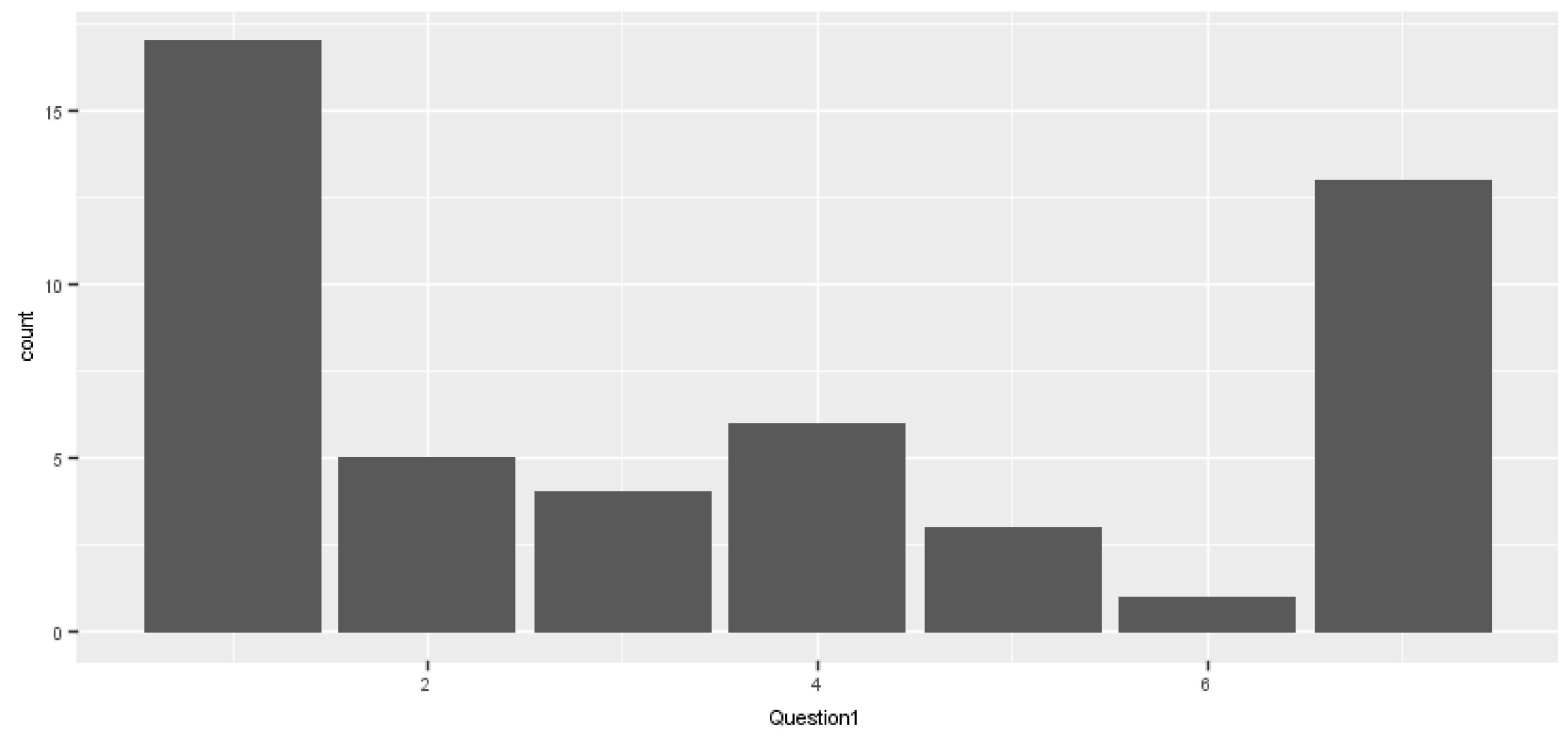

Figure 3. Distribution of the answers to Question 1: Q1-Does your company identify (check) stakeholders and clients before starting projects? Source: own work.

As shown in Figure 3, 22 of the respondents (44.9\%) indicated that their company "definitely no" or "almost no" identified (check) stakeholders and clients before starting projects, while the answer "definitely yes" or "basically yes" was given by 14 of the respondents $(28.5 \%)$. The answer "slightly", "to a moderate extent", or "pretty much" was given 13 respondents $(26.5 \%)$.

If the respondents answered "definitely no" or "hard to say" to question 1 , then they were asked to answer question 2: Q2-Does your company plan to identify (check) stakeholders in the future? As shown by the conducted research, $91 \%$ of the respondents answered "definitely no" or "almost no", while the answer "definitely yes" or "basically yes" was given by $4 \%$ of the respondents, and the answer "slightly", "to a moderate extent", or "pretty much" was given by $4 \%$ of the respondents.

If the respondents answered "almost no" or "slightly" or "to a moderate extent" or "pretty much" or "basically yes" or "definitely yes" to question 1, they were asked to answer questions 3, 4, and 5. For Q3-What is used to identify stakeholders?, in total, 15\% of the respondents indicated checklists, $26 \%$ indicated document analysis, 37\% indicated informal knowledge of the members of the organization, $52 \%$ indicated conversations and brainstorming, and 19\% indicated other. For Q4-Is the identification of stakeholders continued during the project implementation?, as shown by the conducted research, $17 \%$ of the respondents answered "definitely no" or "almost no", while the answer "definitely yes" or "basically yes" was given by $48 \%$ of the respondents and the answers "slightly", "to a moderate extent", or "pretty much" was given by $31 \%$ of the respondents (answer "hard to say" 3\% of respondents). For Q5-Does your company perform stakeholder analysis in a formalized way before starting projects?, as shown by the conducted research, $28 \%$ of the respondents answered "definitely no" or "almost no", while the answer "definitely yes" or "basically yes" was given by $24 \%$ of the respondents, and the answer "slightly", "to a 
moderate extent", or "pretty much" was given by $45 \%$ of the respondents (answer "hard to say" $3 \%$ of respondents).

If the respondents answered "definitely no" or "hard to say" to question 5, then they were asked to answer question6: Q6-Does your company expect to conduct a formal stakeholder analysis before starting projects in the future? As shown by the conducted research, $56 \%$ of the respondents answered "definitely no" or "almost no", while the answer "definitely yes" or "basically yes" was given by 11 of the respondents, and the answer "slightly", "to a moderate extent", or "pretty much" was given by $22 \%$ of the respondents (answer "hard to say" $11 \%$ of respondents).

If the respondents answered "almost no" or "slightly" or "to a moderate extent" or "pretty much" or "basically yes" or "definitely yes" to question 5, then they were asked to answer question 7: Q7-What criteria are used in the stakeholder analysis? In total, 30\% of the respondents indicated the strength of an impact on the project, $45 \%$ indicated the nature of the impact (positive $\backslash$ negative), $45 \%$ indicated interest in the project, and 35\% indicated the predictability of the stakeholder, $80 \%$ indicated the nature of the relations with the stakeholder (formal agreement, legal, social, ethical responsibility).

If the respondents answered "almost no" or "slightly" or "to a moderate extent" or "pretty much" or "basically yes" or "definitely yes" to question 1, then they were asked to answer question 8 and question 9: Q8-Are unused criteria for stakeholder analysis foreseen in the near future? As shown by the conducted research, $45 \%$ of the respondents answered "definitely no" or "almost no", while the answer "definitely yes" or "basically yes" was given by $17 \%$ of the respondents, and the answer "slightly", "to a moderate extent", or "pretty much" was given by $24 \%$ of the respondents (answer "hard to say" $14 \%$ of respondents). For Q9-Is an action and communication strategy developed for the group of the most important stakeholders selected during the analysis in a systematic manner?, as shown by the conducted research, $31 \%$ of the respondents answered "definitely no" or "almost no", while the answer "definitely yes" or "basically yes" was given by $21 \%$ of the respondents, and the answer "slightly", "to a moderate extent", or "pretty much" was given by $48 \%$ of the respondents.

If the respondents answered "definitely no" or "hard to say" to question 9, then they were to asked answer question 10: Q10-Is systematic development of activities and communication towards stakeholders envisaged in the near future? As shown by the conducted research, 78\% of the respondents answered "definitely no" or "almost no", while the answer "definitely yes" or "basically yes" was given by $0 \%$ of the respondents, and the answer "slightly", "to a moderate extent", or "pretty much" was given by $11 \%$ of the respondents (answer "hard to say" 11\% of respondents).

If the respondents answered "almost no" or "slightly" or "to a moderate extent" or "pretty much" or "basically yes" or "definitely yes" to question 9, then they were asked to answer question 11: Q11-Is there any significant modification to the way activities and stakeholder communication are foreseen in the near future? As shown by the conducted research, $40 \%$ of the respondents answered "definitely no" or "almost no", while the answer "definitely yes" or "basically yes" was given by $20 \%$ of the respondents, and the answer "slightly", "to a moderate extent", or "pretty much" was given by $40 \%$ of the respondents.

As shown in Figure 4, five of the respondents (8.2\%), regarding the current way of communicating with stakeholders before project implementation, answered "definitely no" or "almost no" to allowing them to get to know their needs, expectations, and attitudes towards the project, while the answer "definitely yes" or "basically yes" was given by 31 of the respondents (63.3\%). The answer "slightly", "to a moderate extent", or "pretty much" was given by a total of 13 respondents $(26.5 \%)$.

As shown in Figure 5, 30 respondents (62.5\%) indicated that in the near future, "definitely no" or "almost no" significant modification of the way of contacting stakeholders before a project's implementation is planned, while the answer "definitely yes" or "basically yes" was given by 6 of the respondents (12.5\%). The answer "slightly", "to a moderate extent", or "pretty much" was given by a total of 12 respondents (25\%). 


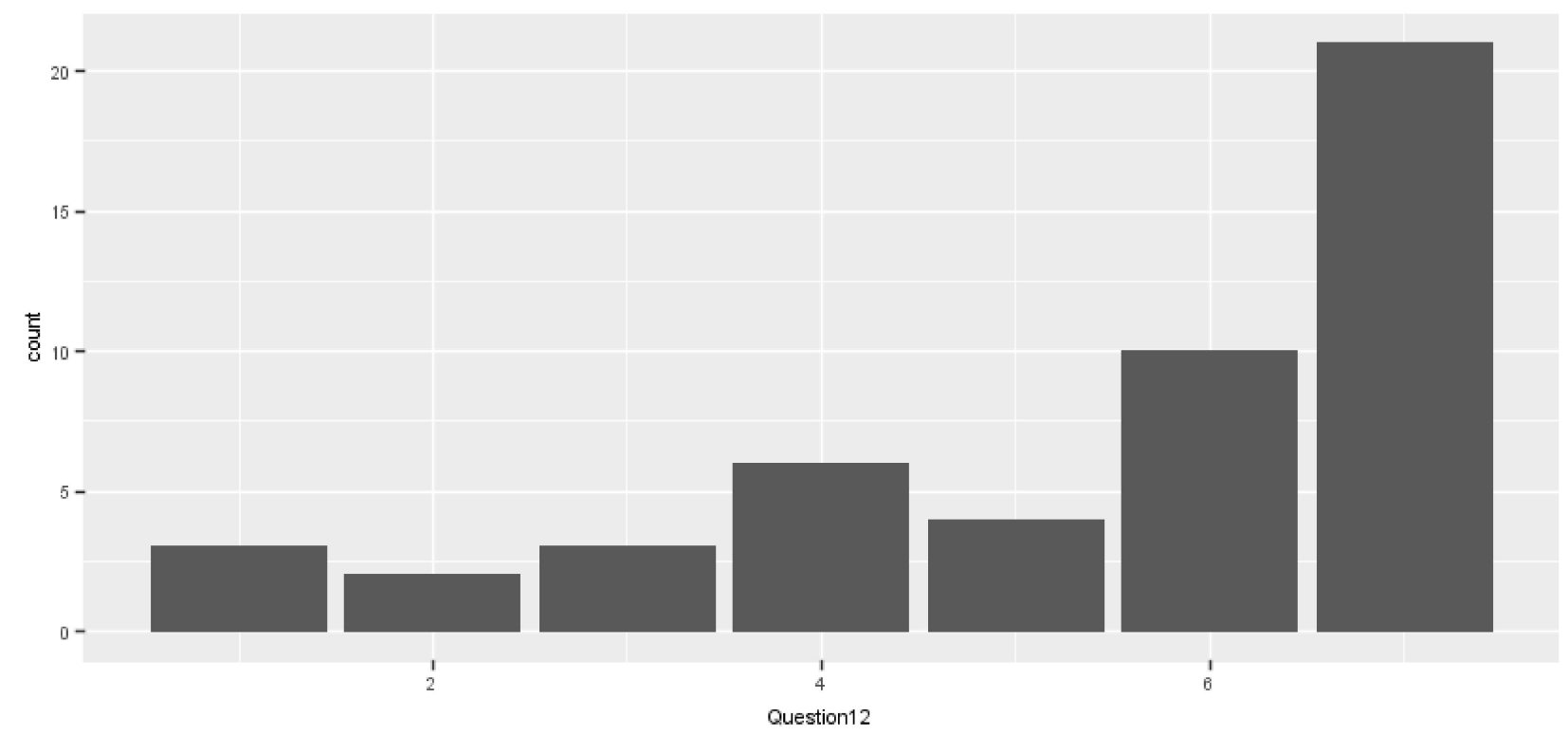

Figure 4. Distribution of the answers to question 12: Q12-Does the current way of communicating with the stakeholders before the project implementation sufficiently allow to get to know their needs, expectations and attitudes towards the project? Source: own work.

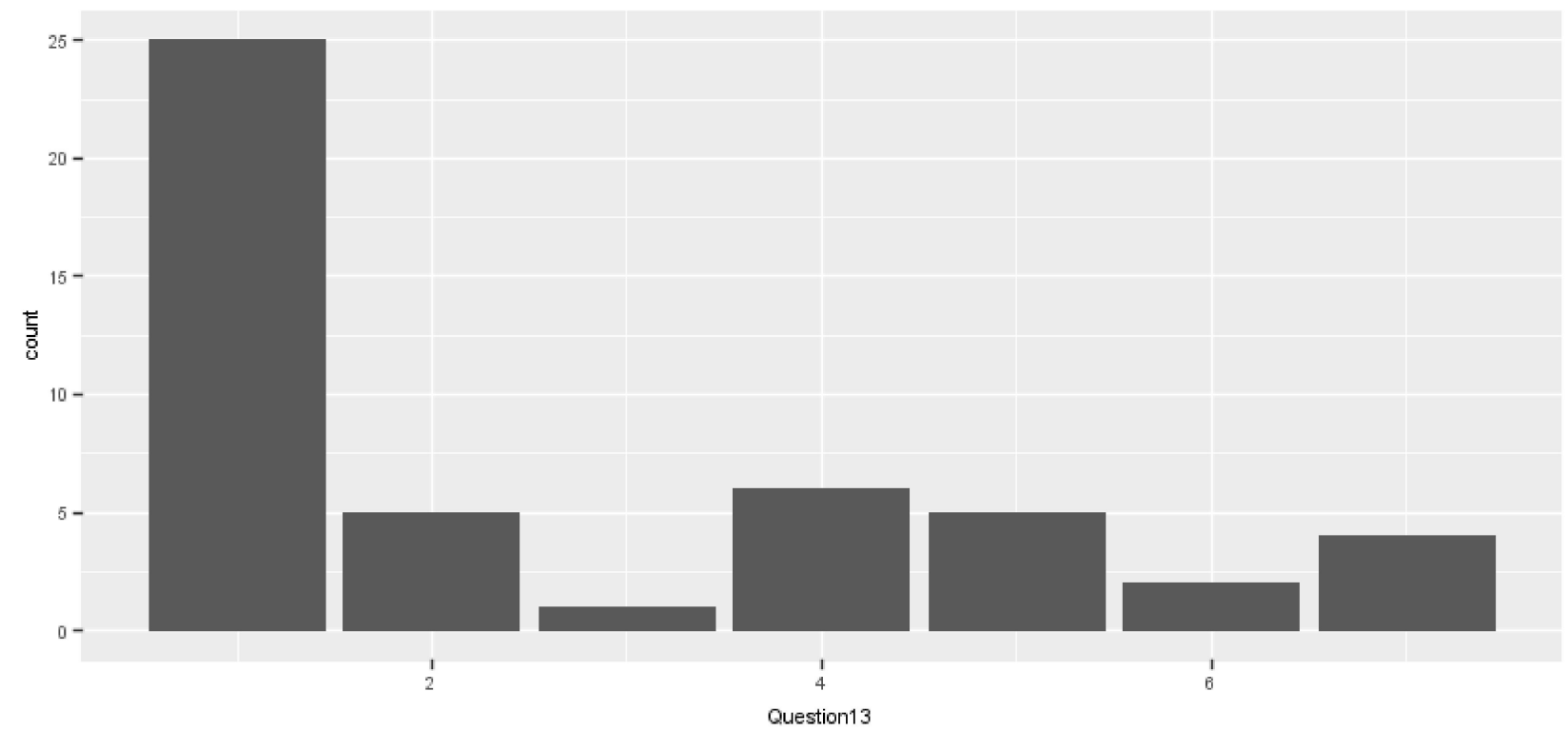

Figure 5. Distribution of the answers to question 13: Q13-Is any significant modification to the way of contacting stakeholders before project implementation planned in the near future? Source: own work.

As shown in Figure 6, 9 of the respondents (18.4\%) indicated "definitely no" or "almost no" to the statement that communication with stakeholders during project implementation allows sufficient identification of the possible evolution of their needs, expectations, and attitudes towards the project, while the answer "definitely yes" or "basically yes" was given by 25 of the respondents ( $51 \%)$. The answer "slightly", "to a moderate extent", or "pretty much" was given by a total of 15 respondents (30.7\%).

As shown in Figure 7, 30 of the respondents $(60 \%)$ indicated "definitely no" or "almost no" to the statement that in the near future, a significant modification of the way of contacting stakeholders during project implementation is planned, while the answer "definitely yes" or "basically yes" was given by 5 of the respondents $(10 \%)$. The answer "slightly", "to a moderate extent", or "pretty much" was given by a total of 15 respondents $(30 \%)$. 


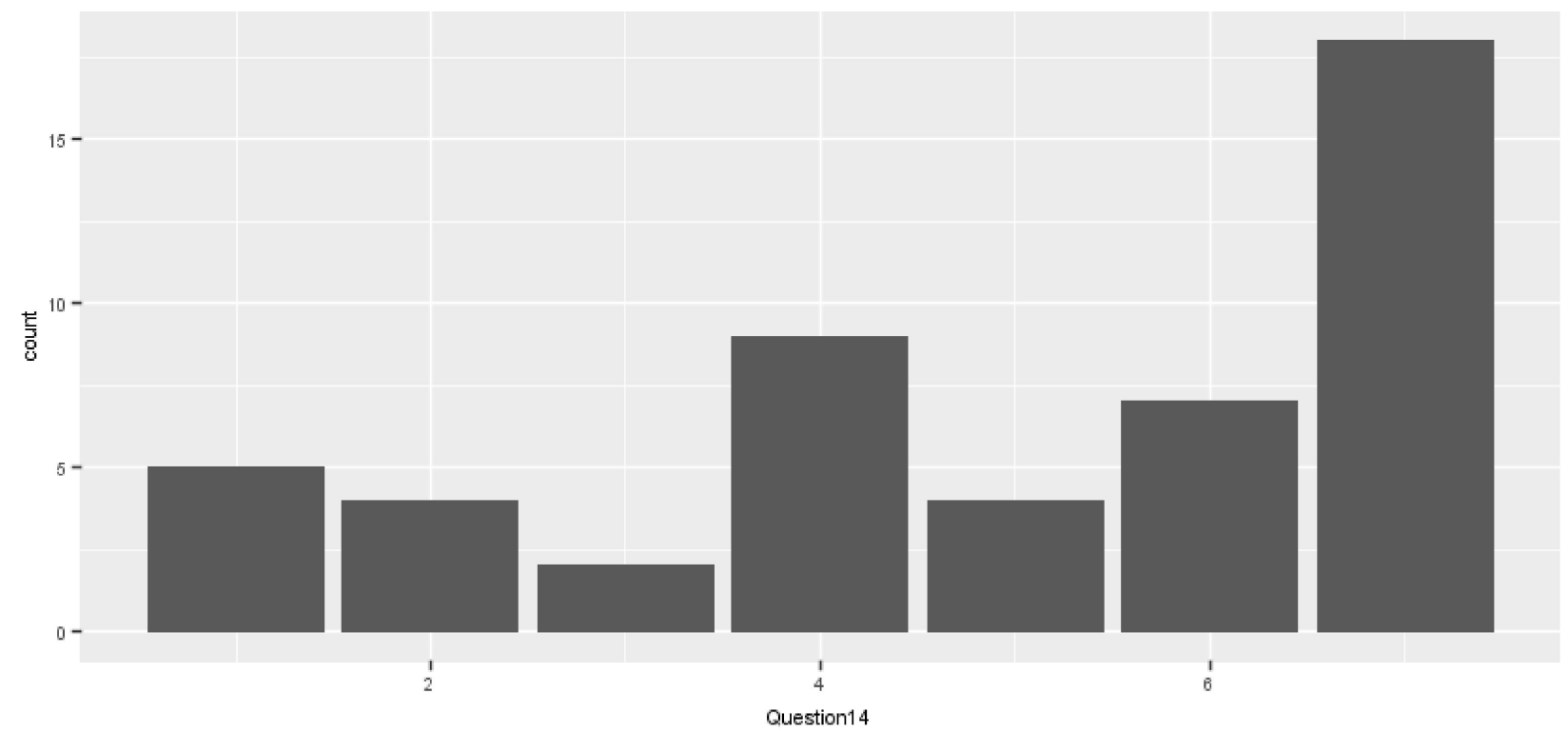

Figure 6. Distribution of the answers to question 14: Q14-Does communication with stakeholders during project implementation allow sufficient identification of possible evolution of their needs, expectations, and attitudes towards the project? Source: own work.

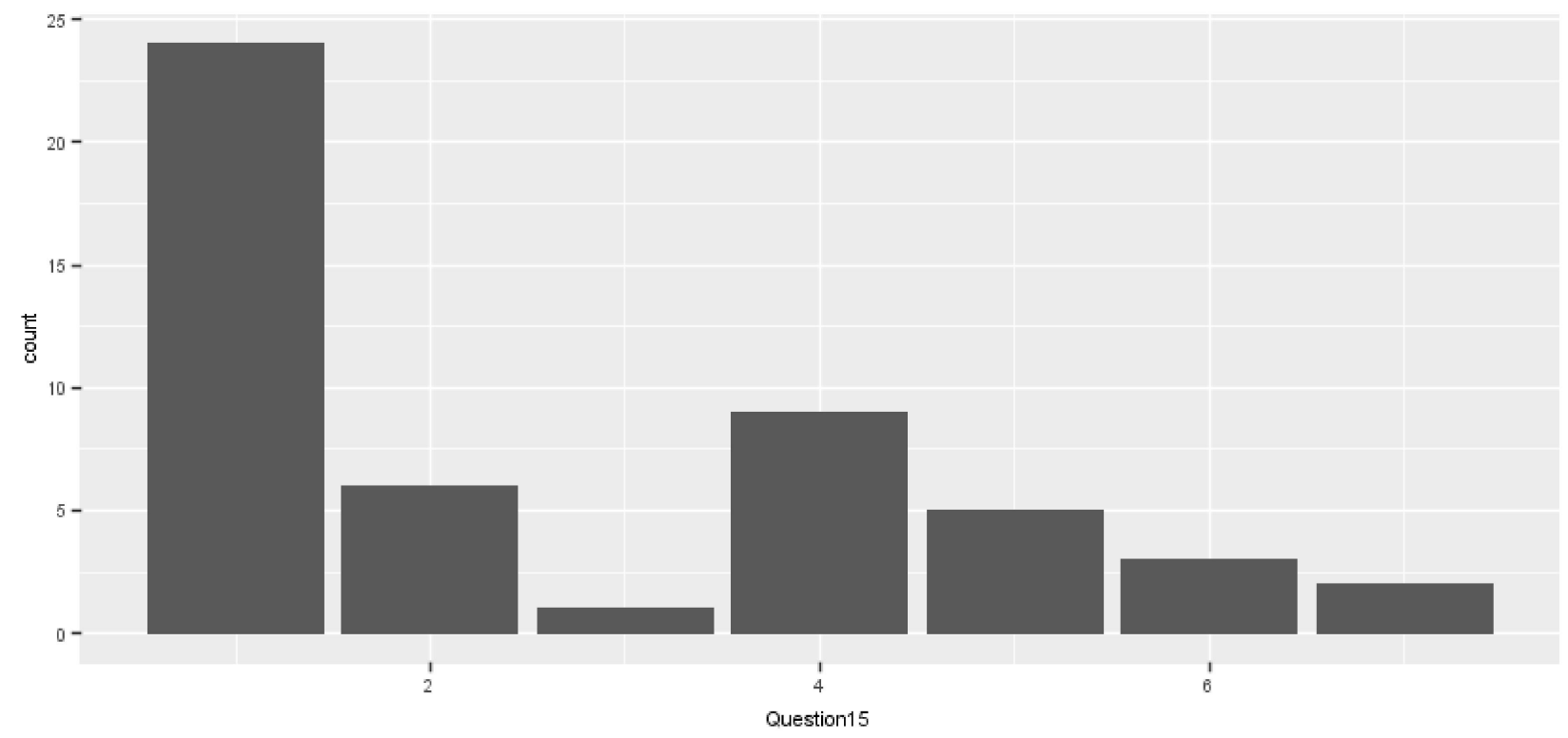

Figure 7. Distribution of answers to question 15: Q15-Is any significant modification to the way of contacting stakeholders during project implementation planned in the near future? Source: own work.

\section{Correlations}

The results of the study of the area of stakeholder management in project management in construction companies, including the analysis of the correlation of the variables present in the study, will be presented later in the study. As the answers for questions were categorical variables, they are presented as frequencies with percentages. Correlations were analyzed with Spearman's rank correlations and shown graphically on scatter plots with $95 \%$ confidence intervals. A two-sided $p$ value of $<0.05$ was considered statistically significant. All analyses were performed using $\mathrm{R}$ version 3.4.4 (R Foundation for Statistical Computing, Vienna, Austria). The correlation was calculated for the five questions from the main part of the questionnaire: Questions Q1, Q12, Q13, Q14, and Q15 considering four questions from the metric: Questions Q16, Q18, Q20, and Q21, hereinafter referred to 
demographics 16 (the number of employees), demographics 18 (conducting international cooperation), demographics 20 (date of commencement of operations), and demographics 21 (respondent's function in the organization). The correlations are shown in Figures 8-12.

Questions Q1, Q12, Q13, Q14, and Q15 were selected for the analysis because they concerned the entire research sample, i.e., 50 construction companies. On the other hand, answers to the remaining questions from Q2 to Q11 were provided by only some of the respondents, depending on the answers given to the previous questions.

Q1-Does your company identify (check) stakeholders and clients before starting projects?

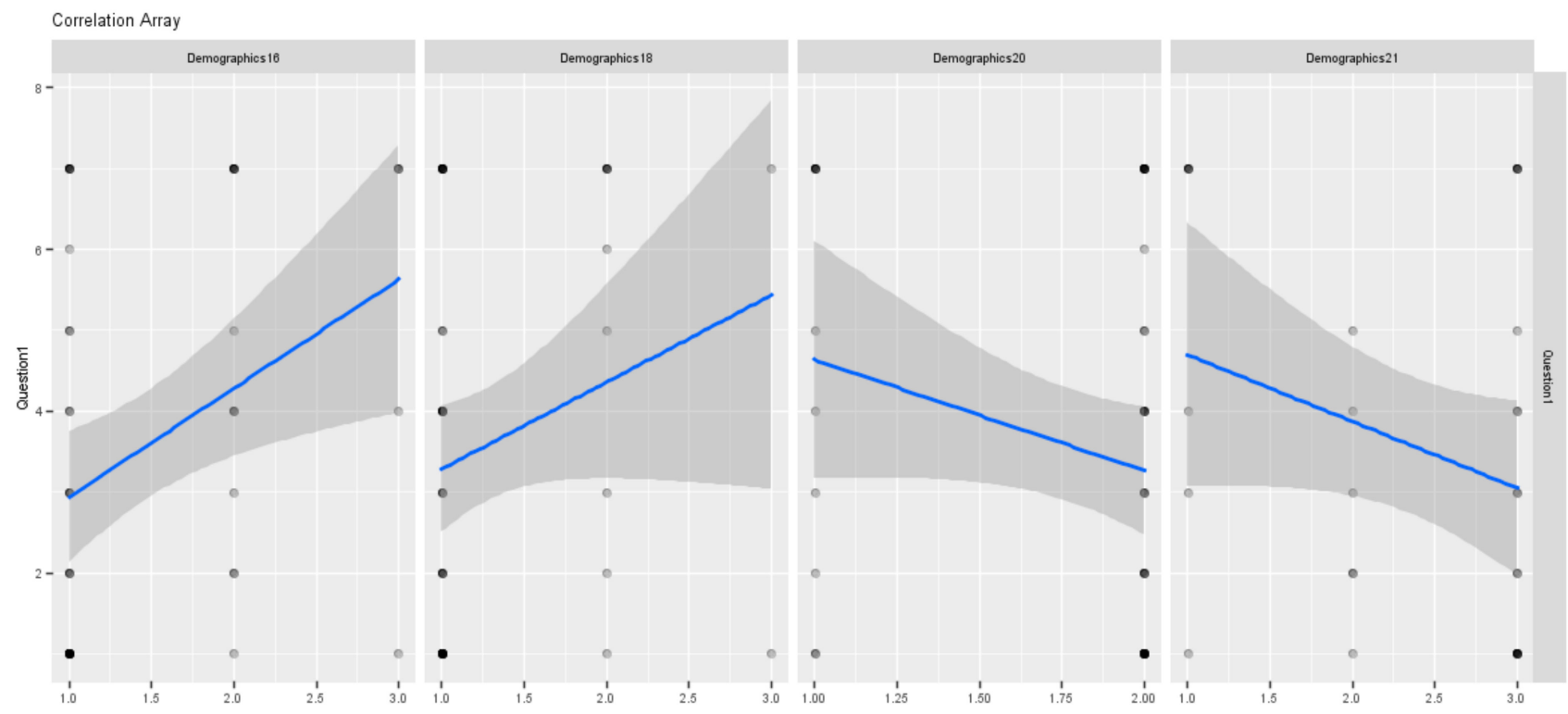

Figure 8. Correlation question 1 (Q1-Does your company identify (check) stakeholders and clients before starting projects?) vs. Demographics16, 18, 20, and 21. Source: own work.

Table 3 presents the results of the correlation analysis for question 1 and its conclusions.

Table 3. Spearman's rank correlation (question 1 vs. demographics 16, 18, 20, and 21).

\begin{tabular}{|c|c|c|}
\hline & $\begin{array}{l}\text { Spearman's Rank } \\
\text { Correlation }\end{array}$ & $\begin{array}{l}\text { Question1: Q1-Does Your Company Identify (Check) Stakeholders and Clients } \\
\text { before Starting Projects? }\end{array}$ \\
\hline $\begin{array}{l}\text { Demographics } 16 \text { (the } \\
\text { number of employees) }\end{array}$ & $\mathrm{r}=0.3969 ; p=0.0048$ & $\begin{array}{l}\text { Conclusions: } \\
\text { The frequency of conducting stakeholder and customer identification (checking) before } \\
\text { starting projects significantly positively correlates with the number of employees in the } \\
\text { company (the larger the company, the more often it checks stakeholders and customers } \\
\text { before starting projects). Average correlation. }\end{array}$ \\
\hline $\begin{array}{l}\text { Demographics } 18 \\
\text { (conducting international } \\
\text { cooperation) }\end{array}$ & $\mathrm{r}=0.249 ; p=0.0845$ & $\begin{array}{l}\text { Conclusions: The frequency of conducting stakeholder and customer identification } \\
\text { (checking) before starting projects significantly positively correlates with the company's } \\
\text { openness to foreign markets (the more open the company is to foreign markets, the more } \\
\text { often it checks stakeholders and customers before starting projects). Weak correlation. }\end{array}$ \\
\hline $\begin{array}{l}\text { Demographics } 20 \text { (date of } \\
\text { commencement of } \\
\text { operations) }\end{array}$ & $\mathrm{r}=-0.2359 ; p=0.1027$ & $\begin{array}{l}\text { Conclusions: The frequency of conducting stakeholder and customer identification } \\
\text { (checking) before starting projects non-significantly negatively correlates with firm } \\
\text { formation after } 1990 \text { (the younger the firm, the less often customers and stakeholders are } \\
\text { checked before starting projects). Correlation weak and not significant. }\end{array}$ \\
\hline $\begin{array}{l}\text { Demographics } 21 \\
\text { (respondent's function in } \\
\text { the organization) }\end{array}$ & $\mathrm{r}=-0.2688 ; p=0.1437$ & $\begin{array}{l}\text { Conclusions: The frequency of conducting stakeholder and customer identification } \\
\text { (checking) before starting projects non-significantly negatively correlates with the } \\
\text { importance of the position held by the respondent (the higher the respondent in the } \\
\text { company hierarchy, the less frequently customers and stakeholders are checked before } \\
\text { starting projects). Correlation weak and not significant. We can also conclude that the } \\
\text { easier it is to talk to the most important person in the company, the smaller and younger } \\
\text { the company is, which is consistent with the answer to questions Q18 and Q20. }\end{array}$ \\
\hline
\end{tabular}


Q12-Does the current way of communicating with the stakeholders before the project implementation sufficiently allow them to get to know their needs, expectations, and attitudes towards the project?

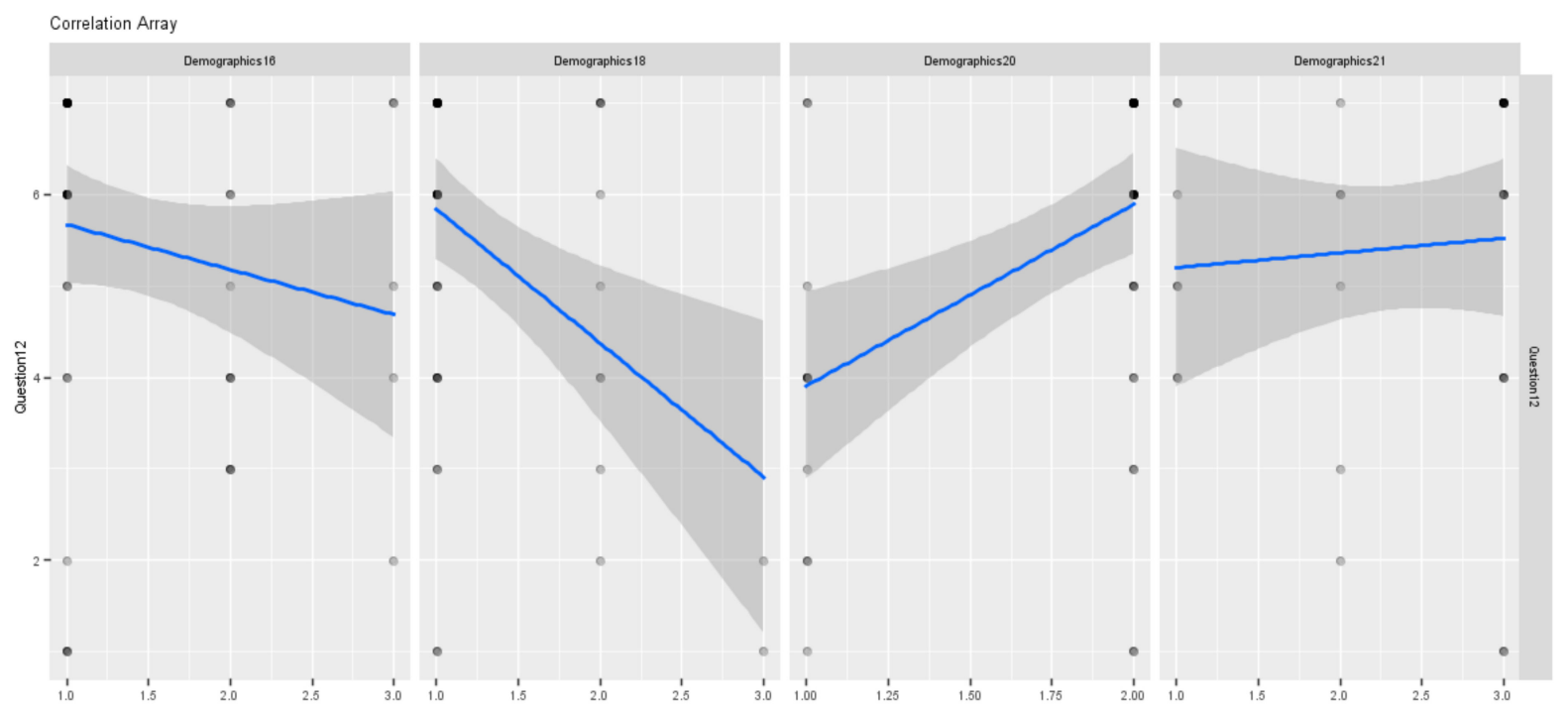

Figure 9. Correlation question 12 (Q12-Does the current way of communicating with the stakeholders before the project implementation sufficiently allow them to get to know their needs, expectations, and attitudes towards the project?) vs. demographics 16, 18, 20, and 21. Source: own work.

Table 4 presents the results of the correlation analysis for question 12 and its conclusions.

Table 4. Spearman's rank correlation (question 12 vs. demographics 16, 18, 20, and 21).

\section{Spearman's Rank}

Correlation

Demographics16 (the number of employees)

$\mathrm{r}=-0.2355 ; p=0.1033$

Question 12: Q12-Does the Current Way of Communicating with the Stakeholders before the Project Implementation Sufficiently Allow Them to Get to Know Their Needs, Expectations, and Attitudes towards the Project?

Conclusions: The current method of communication with stakeholders prior to project implementation allows one to learn about their needs, expectations, and attitudes towards the project non-significantly negatively correlates with the number of employees employed in the company (the larger the company, the less frequently the current method of communication with stakeholders prior to project implementation allows one to learn about their needs, expectations, and attitudes towards the project). Weak correlation

Conclusions: The current method of communication with stakeholders prior to project implementation allows one to learn about their needs, expectations, and attitudes towards the project non-significantly negatively correlates with the company's opening to foreign markets (the more open the company is to foreign markets, the less frequently the current method of communication with stakeholders prior to project implementation allows one to learn about their needs, expectations, and attitudes towards the project). Weak correlation

(conducting international $\quad \mathrm{r}=-0.3017 ; p=0.3552$ cooperation)

Conclusions: The current method of communication with stakeholders before project implementation allows one to know their needs, expectations, and attitudes towards the project non-significantly negatively correlates with the establishment of the company after 1990 (the younger the company, the less often the current way of communication with stakeholders before project implementation allows one to know their needs, expectations, and attitudes towards the project). Average correlation

commencement of $\quad \mathrm{r}=-0.4223 ; p=0.0025$ operations)

\section{Demographics21}

(respondent's function in $\quad \mathrm{r}=0.1949 ; p=0.2633$ the organization)
Conclusions: The current method of communication with stakeholders before project implementation allows one to learn their needs, expectations, and attitudes towards the project significantly positively correlates with the importance of the position held by the respondent (the higher the respondent in the hierarchy of the company, the more often the current method of communication with stakeholders before project implementation allows one to learn their needs, expectations, and attitudes towards the project). Weak correlation 
Q13-Is any significant modification to the way of contacting stakeholders before the project implementation planned in the near future?



Figure 10. Correlation question 13 (Q13-Is any significant modification to the way of contacting stakeholders before the project implementation planned in the near future?) vs. demographics16, 18, 20, and 21. Source: own work.

Table 5 presents the results of the correlation analysis for question 13 and its conclusions.

Table 5. Spearman's rank correlation (question13 vs. demographics 16, 18, 20, and 21).

\begin{tabular}{|c|c|c|}
\hline & $\begin{array}{l}\text { Spearman's Rank } \\
\text { Correlation }\end{array}$ & $\begin{array}{l}\text { Question13: Q13-Is Any Significant Modification to the Way of Contacting } \\
\text { Stakeholders before the Project Implementation Planned in the Near Future? }\end{array}$ \\
\hline $\begin{array}{l}\text { Demographics } 16 \text { (the } \\
\text { number of employees) }\end{array}$ & $\mathrm{r}=0.3099 ; p=0.8344$ & $\begin{array}{l}\text { Conclusions: In the near future, the anticipated significant modification of the } \\
\text { method of contacting stakeholders before project implementation significantly } \\
\text { positively correlates with the number of employees in the company (the larger the } \\
\text { company, the more often the anticipated significant modification of the method of } \\
\text { contacting stakeholders before project implementation in the near future). } \\
\text { Weak correlation }\end{array}$ \\
\hline $\begin{array}{l}\text { Demographics } 18 \\
\text { (conducting international } \\
\text { cooperation) }\end{array}$ & $\mathrm{r}=0.02953 ; p=0.8421$ & $\begin{array}{l}\text { Conclusions: In the near future, the anticipated significant modification of the } \\
\text { method of contacting stakeholders prior to project implementation significantly } \\
\text { positively correlates with the company's opening to foreign markets (the more open } \\
\text { the company is to foreign markets, the more often the significant modification of the } \\
\text { method of contacting stakeholders prior to project implementation is anticipated in } \\
\text { the near future). Weak correlation }\end{array}$ \\
\hline $\begin{array}{l}\text { Demographics20 (date of } \\
\text { commencement of } \\
\text { operations) }\end{array}$ & $\mathrm{r}=0.3291 ; p=0.8243$ & $\begin{array}{l}\text { Conclusions: In the near term, anticipated significant modification in how } \\
\text { stakeholders are contacted prior to project implementation significantly positively } \\
\text { correlates with having established the firm after } 1990 \text { (the younger the firm, the } \\
\text { more likely it is to anticipate significant modification in how stakeholders are } \\
\text { contacted prior to project implementation in the near term). Weak correlation }\end{array}$ \\
\hline $\begin{array}{l}\text { Demographics } 21 \\
\text { (respondent's function in } \\
\text { the organization) }\end{array}$ & $\mathrm{r}=-0.1744 ; p=0.3567$ & $\begin{array}{l}\text { Conclusions: In the near future, the anticipated significant modification of the } \\
\text { method of contacting stakeholders prior to project implementation non-significantly } \\
\text { negatively correlates with the importance of the position held by the respondent (the } \\
\text { higher the respondent in the hierarchy of the company, the less often significant } \\
\text { modification of the method of contacting stakeholders prior to project } \\
\text { implementation is anticipated in the near future). Weak correlation }\end{array}$ \\
\hline
\end{tabular}

Source: own work.

Q14-Does communication with stakeholders during project implementation sufficiently allow identification of possible evolution of their needs, expectations, and attitudes towards the project? 


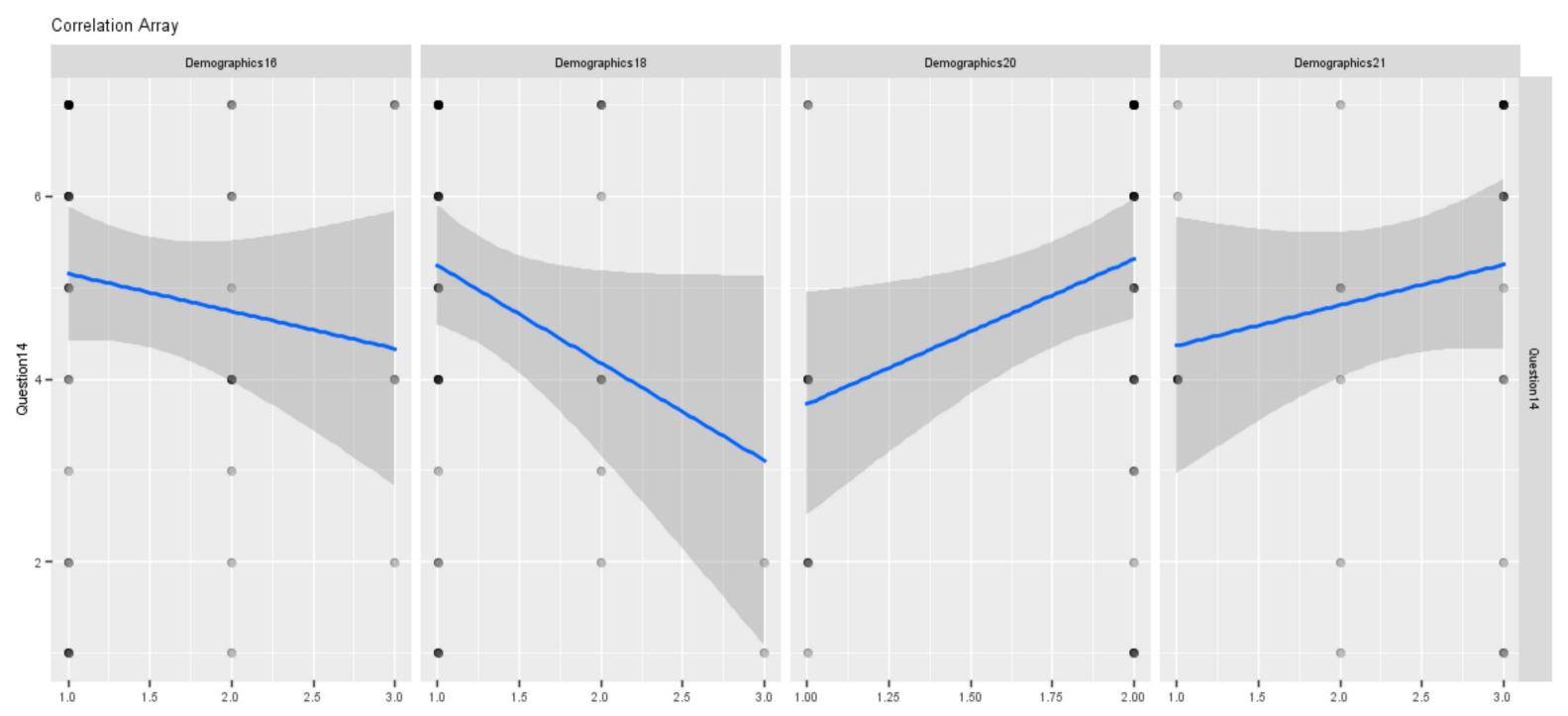

Figure 11. Correlation question 14 (Q14-Does communication with stakeholders during project implementation sufficiently allow identification of possible evolution of their needs, expectations, and attitudes towards the project?) vs. demographics $16,18,20$, and 21. Source: own work.

Table 6 presents the results of the correlation analysis for question 14 and its conclusions.

Table 6. Spearman's rank correlation (question 14 vs. demographics 16, 18, 20, and 21).

\begin{tabular}{|c|c|c|}
\hline & $\begin{array}{c}\text { Spearman's Rank } \\
\text { Correlation }\end{array}$ & $\begin{array}{c}\text { Question 14: Q14-Does Communication with Stakeholders during Project } \\
\text { Implementation Sufficiently Allow Identification of Possible Evolution of Their } \\
\text { Needs, Expectations, and Attitudes Towards the Project? }\end{array}$ \\
\hline $\begin{array}{l}\text { Demographics } 16 \text { (the } \\
\text { number of employees) }\end{array}$ & $\mathrm{r}=-0.1924 ; p=0.1854$ & $\begin{array}{l}\text { Conclusions: Communication with stakeholders during project implementation } \\
\text { allows identification of the possible evolution of their needs, expectations, and } \\
\text { attitudes towards the project insignificantly negatively correlates with the number of } \\
\text { employees employed in the company (the larger the company, the less often } \\
\text { communication with stakeholders during project implementation allows } \\
\text { identification of the possible evolution of their needs, expectations, and attitudes } \\
\text { towards the project). Weak correlation }\end{array}$ \\
\hline $\begin{array}{l}\text { Demographics } 18 \\
\text { (conducting international } \\
\text { cooperation) }\end{array}$ & $\mathrm{r}=-0.1984 ; p=0.1718$ & $\begin{array}{l}\text { Conclusions: Communication with stakeholders during project implementation } \\
\text { allows identification of the possible evolution of their needs, expectations, and } \\
\text { attitude towards the project non-significantly negatively correlates with the } \\
\text { company's opening to foreign markets (the more open the company is to foreign } \\
\text { markets, the less often communication with stakeholders during project } \\
\text { implementation allows identification of the possible evolution of their needs, } \\
\text { expectations, and attitude towards the project). Weak correlation }\end{array}$ \\
\hline $\begin{array}{l}\text { Demographics } 20 \text { (date of } \\
\text { commencement of } \\
\text { operations) }\end{array}$ & $\mathrm{r}=0.3158 ; p=0.0271$ & $\begin{array}{l}\text { Conclusions: Communication with stakeholders during project implementation } \\
\text { allows identification of the possible evolution of their needs, expectations, and } \\
\text { attitudes towards the project significantly positively correlates with the } \\
\text { establishment of the company after } 1990 \text { (the younger the company, the more often } \\
\text { communication with stakeholders during project implementation allows } \\
\text { identification of the possible evolution of their needs, expectations, and attitudes } \\
\text { towards the project). Weak correlation }\end{array}$ \\
\hline $\begin{array}{l}\text { Demographics } 21 \\
\text { (respondent's function in } \\
\text { the organization) }\end{array}$ & $\mathrm{r}=0.2965 ; p=0.1053$ & $\begin{array}{l}\text { Conclusions: Communication with stakeholders during project implementation } \\
\text { allows identification of the possible evolution of their needs, expectations, and } \\
\text { attitude towards the project significantly positively correlates with the importance of } \\
\text { the position held by the respondent (the higher the respondent in the hierarchy of } \\
\text { the company, the more often communication with stakeholders during project } \\
\text { implementation allows identification of the possible evolution of their needs, } \\
\text { expectations, and attitude towards the project). Weak correlation }\end{array}$ \\
\hline
\end{tabular}

Source: own work.

Q15-Is any significant modification to the way of contacting stakeholders during the project implementation planned in the near future? 




Figure 12. Correlation question 15 (Q15-Is any significant modification to the way of contacting stakeholders during the project implementation planned in the near future?) vs. demographics 16, 18, 20, and 21. Source: own work.

Table 7 presents the results of the correlation analysis for question 15 and its conclusions.

Table 7. Spearman's rank correlation (question 15 vs. demographics 16, 18, 20, and 21).

\begin{tabular}{|c|c|c|}
\hline & $\begin{array}{l}\text { Spearman's Rank } \\
\text { Correlation }\end{array}$ & $\begin{array}{l}\text { Question 15: Q15-Is Any Significant Modification to the Way of Contacting } \\
\text { Stakeholders during the Project Implementation Planned in the Near Future? }\end{array}$ \\
\hline $\begin{array}{l}\text { Demographics } 16 \text { (the } \\
\text { number of employees) }\end{array}$ & $\mathrm{r}=0.2196 ; p=0.1255$ & $\begin{array}{l}\text { Conclusions: Significant modification of the method of contacting stakeholders } \\
\text { during project execution expected in the near future positively correlates with the } \\
\text { number of employees in the company (the larger the company, the more often } \\
\text { significant modification of the method of contacting stakeholders during project } \\
\text { execution is expected in the near future). Weak correlation }\end{array}$ \\
\hline $\begin{array}{l}\text { Demographics } 18 \\
\text { (conducting international } \\
\text { cooperation) }\end{array}$ & $\mathrm{r}=-0.09034 ; p=0.5327$ & $\begin{array}{l}\text { Conclusions: In the near future, the expected significant modification of the method } \\
\text { of contacting stakeholders during project implementation non-significantly } \\
\text { negatively correlates with the company's opening to foreign markets (the more open } \\
\text { a company is to foreign markets, the less often it is expected in the near future to } \\
\text { significantly modify the method of contacting stakeholders during project } \\
\text { implementation). Weak correlation }\end{array}$ \\
\hline $\begin{array}{l}\text { Demographics20 (date of } \\
\text { commencement of } \\
\text { operations) }\end{array}$ & $0.3743 ; p=0.0074$ & $\begin{array}{l}\text { Conclusions: In the near future, the anticipated significant modification of the way } \\
\text { of contacting stakeholders during project implementation non-significantly } \\
\text { negatively correlates with the establishment of the company after } 1990 \text { (the younger } \\
\text { the company, the less often the anticipated significant modification of the way of } \\
\text { contacting stakeholders during project implementation in the near future). } \\
\text { Weak correlation }\end{array}$ \\
\hline $\begin{array}{l}\text { Demographics } 21 \\
\text { (respondent's function in } \\
\text { the organization) }\end{array}$ & $\mathrm{r}=-0.2193 ; p=0.2279$ & $\begin{array}{l}\text { Conclusions: Significant modification of the method of contacting stakeholders } \\
\text { during project execution expected in the near future negatively correlates with the } \\
\text { importance of the position held by the respondent (the higher the respondent in the } \\
\text { hierarchy of the company, the less often a significant modification of the method of } \\
\text { contacting stakeholders during project execution is expected in the near future). } \\
\text { Weak correlation }\end{array}$ \\
\hline
\end{tabular}

Source: own work.

\section{Discussion and Conclusions}

The research results indicate a low level of maturity of small construction companies in managing project stakeholders (visible in the lack of developed approaches to project stakeholder management, lack of stakeholder identification and analysis, lack of application of stakeholder management plans), which is a surprising result considering the fact that the literature on the subject emphasizes the importance of taking care of the project stakeholder management area and links it with the project's achievement of success. It is even more surprising as from the point of view of sustainability, the attitude of stakeholders to this concept and their experience in this area determines whether the project will contribute 
to sustainable development and whether it will be executed with its principles [3], which has significant value in construction projects [101]. Moreover, according to [4] in the published studies on sustainability in project management, the building/construction industry is well represented. According to [91], achieving sustainability-related targets in construction projects is increasingly becoming a key performance driver and there is a need for a systematic approach to engage stakeholders with high importance in relation to sustainability. The research presented here revealed six steps to the stakeholder engagement process: identification, relating stakeholders to different sustainability-related targets, prioritization, managing, measuring performance, and putting targets into action. On the other hand, the results discussed in this paper in a certain sense correspond to research conducted in Brazil [100], where some social issues related to stakeholders need to be worked, and in the Netherlands [9], where people and planet performance indicators in the management and delivery of projects are still rarely implemented.

Answers to research question (1), (2), (3), and partially (4) were based on a literature review. Namely, project success is associated with satisfying the various stakeholders of the project and stakeholders' expectations may vary. For effective construction project management, project managers must know stakeholders' opportunities and threats, fulfill social responsibilities, establish common goals, apply appropriate strategies, and enhance stakeholder satisfaction [32]. Generally, one of the types of project success factors is stakeholder management [61]. An extensive number of factors that influence the success and failure of projects exist, but the literature lacks an inclusive categorization in the construction area [62]. However, items that identify and categorize CSF specifically for construction projects can be found. CSF for construction projects have rarely been explicitly named in stakeholder management/analysis, but they largely refer to this aspect (e.g., effective communication, cooperation, clear and precise goals/objectives of the client). One publication [13] directly examined the relationships among critical success factors for stakeholder management in construction. The results of the study showed that stakeholder engagement/empowerment has a direct positive impact on project success. From the sustainability concept point of view, the relationship between sustainable project management (stakeholder management is one of the clues here) and project success has been addressed in several studies and a positive correlation between sustainable project management and project success can be found. It is worth mentioning here that the research was conducted almost a year after the COVID-19 pandemic, which, as the researchers point out, has resulted in a dramatic shift in perceptions of personal and societal values and norms [115]. The literature in the context of stakeholder management for construction projects refers specifically to a large one. In general, many researchers, e.g., the authors of [113], believe that the topic of stakeholder management of construction projects has seldom been explored. Additionally, research findings on stakeholder management of small construction projects are unobtainable. This was considered as a research gap. Therefore, the authors of this publication conducted empirical research that resulted in this publication. Quantitative research provided an answer to research question (5) and supplemented the answer to research question (4).

According to the quantitative research conducted on a sample of 50 construction companies:

- In total, $44.9 \%$ of the respondents indicated "definitely no" or "almost no" to the question that their company identifies (check) stakeholders and clients before starting projects, and $91 \%$ of the respondents answered that their company does not plan to identify (check) stakeholders in the future;

- In total, $63.3 \%$ of the respondents indicated "definitely yes" or "basically yes" to the question that the current way of communicating with stakeholders before the project implementation allows them to get to know their needs, expectations, and attitudes towards the project;

- In total, $62.5 \%$ of the respondents indicated "definitely no" or "almost no" to the question that in the near future, a significant modification of the way of contacting stakeholders before the project implementation is planned; 
- In total, $51 \%$ of the respondents indicated "definitely yes" or "basically yes" to the question that communication with stakeholders during the project implementation allows sufficient identification of the possible evolution of their needs, expectations, and attitudes towards the project;

- In total, $60 \%$ of the respondents indicated "definitely no" or "almost no" to the question that in the near future, a significant modification of the way of contacting stakeholders during the project implementation is planned.

After conducting the correlation analysis, several general conclusions can be drawn, taking into account in particular the size of the construction company, i.e.,

- The larger the company, the more often it checks stakeholders and customers before starting projects;

- The larger the company, the less frequently the current method of communication with stakeholders prior to project implementation allows one to learn about their needs, expectations, and attitudes towards the project;

- The larger the company, the more often significant modification of the method of contacting stakeholders before project implementation is anticipated in the near future;

- The larger the company, the less often communication with stakeholders during project implementation allows identification of the possible evolution of their needs, expectations, and attitudes towards the project;

- The larger the company, the more often significant modification of the method of contacting stakeholders during project execution is expected in the near future.

More detailed conclusions from the analysis of the correlation are presented in Tables 3-7 in the previous part of this article.

This article presents the stakeholder management issue in the context of project success and sustainable project management and presents empirical research in small construction companies in Poland. This study fills a research gap because the literature has focused mainly on large construction projects. This research can also be viewed as empirical evidence that serves as a starting point for future research into stakeholder management in projects.

Given the context of sustainability, small construction companies could consider introducing sustainability reporting because it can help them to assess their performance and communicate their sustainability efforts to their respective stakeholder. One of the ways by which sustainability can trickle down across organizations is by engaging the most important stakeholders. Most of the sustainability reporting frameworks were designed, mainly, for business organizations, but some researchers have attempted to adapt different tools to the needs of other institutions [116].

The chance of successful projects in construction companies (also from the sustainable concept point of view) can be increased through the use of project stakeholder management practices. The results of this study suggest that the success of the project can be achieved through the use of several practices, including:

- Carrying out the identification (checking) of stakeholders and clients before starting projects, and the systematic development of action and communication strategies for the group of the most important stakeholders selected during the analysis;

- Top management should provide additional stakeholder management support to increase the chances of success of their projects.

Although this study provided valuable insights for small projects in particular, it still has some limitations. The research sample was limited due to the context of one country, targeted at one industry and mostly at micro and small enterprises. Future research may be conducted in other contexts, in order to test the generalization and robustness of the results.

Author Contributions: Conceptualization, A.K.-R. and J.I.; Methodology, A.K.-R. and J.I.; Supervision, A.K.-R. and J.I.; Writing-original draft, A.K.-R. and J.I.; Writing-review and editing, A.K.-R. and J.I. All authors have read and agreed to the published version of the manuscript. 
Funding: Not applicable.

Institutional Review Board Statement: In the case of this study, ethical review and approval were waived for this study, due to the fact that the respondents were not asked for any sensitive data, only general data about the company they work for. In addition, all data collected during the study was anonymized.

Informed Consent Statement: Informed consent was obtained from all survey participants involved in the study.

Data Availability Statement: The data presented in this study are available on request from the corresponding author.

Conflicts of Interest: The authors declare no conflict of interest.

\section{Appendix A}

Questions

\begin{tabular}{|c|c|}
\hline Question Q1 & Does your company identify (check) stakeholders and clients before starting projects? \\
\hline Question Q2 & Does your company plan to identify (check) stakeholders in the future? \\
\hline Question Q3 & $\begin{array}{l}\text { What is used to identify stakeholders? } \\
\text { - checklists, } \\
\text { - document analysis, } \\
\text { informal knowledge of the members of the organization, } \\
\text { - conversations, brainstorming, }\end{array}$ \\
\hline Question Q4 & Is the identification of stakeholders continued during the project implementation? \\
\hline Question Q5 & Does your company perform stakeholder analysis in a formalized way before starting projects? \\
\hline Question Q6 & Does your company expect to conduct a formal stakeholder analysis before starting projects in the future? \\
\hline Question Q7 & $\begin{array}{l}\text { What criteria are used in the stakeholder analysis? } \\
\text { - } \quad \text { Strength of impact on the project, } \\
\text { - } \quad \text { Inture of impact (positive } \backslash \text { negative), } \\
\text { - } \quad \text { Predictability of the stakeholder, } \\
\text { - Nature of relations with the stakeholder (formal agreement, legal, social, ethical responsibility), } \\
\text { Other }\end{array}$ \\
\hline Question Q8 & Are unused criteria for stakeholder analysis foreseen in the near future? \\
\hline Question Q9 & $\begin{array}{l}\text { Is an action and communication strategy developed for the group of the most important stakeholders selected during the } \\
\text { analysis in a systematic manner? }\end{array}$ \\
\hline Question Q10 & Is systematic development of activities and communication towards stakeholders envisaged in the near future? \\
\hline Question Q11 & Is there any significant modification to the way activities and stakeholder communication are foreseen in the near future? \\
\hline Question Q12 & $\begin{array}{l}\text { Does the current way of communicating with the stakeholders before the project implementation sufficiently allow to get to } \\
\text { know their needs, expectations and attitudes towards the project? }\end{array}$ \\
\hline Question Q13 & $\begin{array}{l}\text { Is there any significant modification to the way of contacting stakeholders before the project implementation is planned in the } \\
\text { near future? }\end{array}$ \\
\hline Question Q14 & $\begin{array}{l}\text { Does communication with stakeholders during project implementation sufficiently allow to identify possible evolution of their } \\
\text { needs, expectations and attitudes towards the project? }\end{array}$ \\
\hline Question Q15 & $\begin{array}{l}\text { Is there any significant modification to the way of contacting stakeholders during the project implementation planned in the } \\
\text { near future? }\end{array}$ \\
\hline
\end{tabular}


Metric

Question Q16

(Demographics16)

How many employees does your company employ? (under 50, between 50-250, over 250 people)

\begin{tabular}{ll}
\hline Question Q17 & What is the annual revenue generated in your company (PLN)? (below 40 million, 40-200 million, over 200 million) \\
$\begin{array}{l}\text { Question Q18 } \\
\text { (Demographics18) }\end{array}$ & Does your company cooperate internationally? (activity in Poland, within the EU, international outside the EU, global) \\
\hline $\begin{array}{l}\text { Question Q19 } \\
\begin{array}{l}\text { Question Q20 } \\
\text { (Demographics20) }\end{array}\end{array}$ & Who is the main owner of your business? (domestic investor, foreign investor) \\
\hline $\begin{array}{l}\text { Question Q21 } \\
\text { (Demographics21) }\end{array}$ & $\begin{array}{l}\text { Which function do you perform in the organization (choose the closest one)? (Board Member, Business Area Managing } \\
\text { Director, Project/Program/Portfolio Manager, Project Office Director, Other) }\end{array}$ \\
\hline
\end{tabular}

Source: own work, based on [117].

\section{References}

1. Marcelino-Sádaba, S.; González-Jaen, L.F.; Pérez-Ezcurdia, A. Using Project Management as a Way to Sustainability. From a Comprehensive Review to a Framework Definition. J. Clean. Prod. 2015, 99, 1-16. [CrossRef]

2. Huemann, M.; Silvius, G. Projects to Create the Future: Managing Projects Meets Sustainable Development. Int. J. Proj. Manag. 2017, 35, 1066-1070. [CrossRef]

3. Brzozowska, A.; Pabian, A.; Pabian, B. Sustainability in Project Management. A Functional Approach; CRC Press Taylor \& Francis Group: Boca Raton, FL, USA, 2021.

4. Silvius, G. Sustainability as a New School of Thought in Project Management. J. Clean. Prod. 2017, 166, 1479-1493. [CrossRef]

5. Silvius, A.J.G.; Schipper, R.P.J. Sustainability in Project Management: A Literature Review and Impact Analysis. Soc. Bus. 2014, 4, 63-96. [CrossRef]

6. Gilbert Silvius, A.J.; Kampinga, M.; Paniagua, S.; Mooi, H. Considering Sustainability in Project Management Decision Making; An Investigation Using Q-Methodology. Int. J. Proj. Manag. 2017, 35, 1133-1150. [CrossRef]

7. Eskerod, P.; Huemann, M. Sustainable Development and Project Stakeholder Management: What Standards Say. Int. J. Manag. Proj. Bus. 2013, 6, 36-50. [CrossRef]

8. Lock, I.; Seele, P. Theorizing Stakeholders of Sustainability in the Digital Age. Sustain. Sci. 2017, 12, 235-245. [CrossRef]

9. Achman, R. Stakeholders' Perspectives on Sustainability in Project Management. In Sustainability Integration for Effective Project Management; IGI Global: Hershey, PA, USA, 2013. [CrossRef]

10. Zaleski, S.; Michalski, R. Success Factors in Sustainable Management of It Service Projects: Exploratory Factor Analysis. Sustainability 2021, 13, 4457. [CrossRef]

11. Pade, C.; Mallinson, B.; Sewry, D. An Elaboration of Critical Success Factors for Rural ICT Project Sustainability in Developing Countries: Exploring the DWESA Case. J. Inf. Technol. Case Appl. Res. 2008, 10, 32-55. [CrossRef]

12. Perrini, F.; Tencati, A. Sustainability and Stakeholder Management: The Need for New Corporate Performance Evaluation and Reporting Systems. Bus. Strategy Environ. 2006, 15, 296-308. [CrossRef]

13. Molwus, J.J.; Erdogan, B.; Ogunlana, S. Using Structural Equation Modelling (SEM) to Understand the Relationships among Critical Success Factors (CSFs) for Stakeholder Management in Construction. Eng. Constr. Archit. Manag. 2017, 24, 426-450. [CrossRef]

14. Bahadorestani, A.; Karlsen, J.T.; Motahari Farimani, N. A Comprehensive Stakeholder-Typology Model Based on Salience Attributes in Construction Projects. J. Constr. Eng. Manag. 2019, 145, 04019048. [CrossRef]

15. Di Maddaloni, F.; Davis, K. Project Manager's Perception of the Local Communities' Stakeholder in Megaprojects. An Empirical Investigation in the UK. Int. J. Proj. Manag. 2018, 36, 542-565. [CrossRef]

16. Hutchinson, N.J.; O'Leary, T.R.; Ma, T. An Analysis of Stakeholder Management in Design \& Build Projects in South Australia, from a Client's Perspective. In Proceedings of the 22nd International Conference on Advancement of Construction Management and Real Estate, CRIOCM 2017, Melbourne, Australia, 20-23 November 2017; pp. 951-958.

17. Booth, A.; Sutton, A.; Papaioannou, D. Systematic Approaches to a Successful Literature Review; SAGE Publications: Thousand Oaks, CA, USA, 2012.

18. Klaus-Rosińska, A. Sukces Projektów Badawczych i Badawczo-Rozwojowych w Sektorze Nauki; Oficyna Wydawnicza Politechniki Wrocławskiej: Wrocław, Poland, 2019.

19. Cooke-Davies, T. The "Real" Success Factors on Projects. Int. J. Proj. Manag. 2002, 20, 185-190. [CrossRef]

20. Camilleri, E. Project Success: Critical Factors and Behaviours, 1st ed.; Routledge: London, UK, 2011.

21. Zid, C.; Kasim, N.; Soomro, A.R. Effective Project Management Approach to Attain Project Success, Based on Cost-Time-Quality. Int. J. Proj. Organ. Manag. 2020, 12, 133-148. [CrossRef]

22. Shenhar, A.J.; Wideman, R.M. Improving PM: Linking Success Criteria to Project Type; Calgary, 1996. Available online: http: //www.maxwideman.com/papers/improvingpm/improvingpm.pdf (accessed on 1 June 2021).

23. Munns, A.K.; Bjeirmi, B.F. The Role of Project Management in Achieving Project Success. Int. J. Proj. Manag. 1996, 14, 81-87. [CrossRef] 
24. Jugdev, K.; Thomas, J.; Delisle, C. Rethinking Project Management-Old Truths and New Insights. 2001. Available online: https:/ / prism.ucalgary.ca/handle/1880/44252 (accessed on 1 June 2021).

25. Atkinson, R. Project Management: Cost, Time and Quality, Two Best Guesses and a Phenomenon, Its Time to Accept Other Success Criteria. Int. J. Proj. Manag. 1999, 17, 337-342. [CrossRef]

26. Koops, L. Identifying Perspectives of Public Project Managers on Project Success. Int. J. Proj. Manag. 2016, 34, 874-889. [CrossRef]

27. Wirkus, M.; Węsierski, T. Zarządzanie Adaptacyjne Na Przykładzie Programu "Pomorska Kolej Metropolitalna". In Innowacje w Zarządzaniu i Inżynierii Produkcji; Knosala, R., Ed.; Oficyna Wydawnicza Polskiego Towarzystwa Zarzadzania Produkcja: Opole, Poland, 2012; pp. 439-450.

28. Young, T.L. Skuteczne Zarzadzanie Projektami; Helion: Gliwice, Poland, 2006.

29. Westerveld, E. The Project Excellence Model ${ }^{\circledR}$ : Linking Success Criteria and Critical Success Factors. Int. J. Proj. Manag. 2003, 21, 411-418. [CrossRef]

30. Aken, T.G.C. De Weg Naar Project Succes: Eerder via Werkstijl Dan Instrumenten; De Tijdstroom: Utrecht, The Netherlands, 1996.

31. Wirkus, M.; Kusio, E. Zarządzanie Interesariuszami Jako Czynnik Sukcesu Innowacyjnego Projektu. Nauki o Zarzadzaniu 2016, 3 , 126-146.

32. Chan, A.P.C.; Oppong, G.D. Managing the Expectations of External Stakeholders in Construction Projects. Eng. Constr. Archit. Manag. 2017, 24, 736-756. [CrossRef]

33. Pinto, J.K.; Slevin, D.P. The Critical Factors in Successful Project Implementation. IEEE Trans. Eng. Manag. 1987, 34, 22-28. [CrossRef]

34. De Wit, A. Measurement of Project Success. Int. J. Proj. Manag. 1988, 6, 164-170. [CrossRef]

35. Prabhakar, G.P. What Is Project Success: A Literature Review. Int. J. Bus. Manag. 2008, 3, 3-10. [CrossRef]

36. Nguyen, N.H.; Skitmore, M.; Wong, J.K.W. Stakeholder Impact Analysis of Infrastructure Project Management in Developing Countries: A Study of Perception of Project Managers in State-Owned Engineering Firms in Vietnam. Constr. Manag. Econ. 2009, 27, 1129-1140. [CrossRef]

37. Davis, K. Different Stakeholder Groups and Their Perceptions of Project Success. Int. J. Proj. Manag. 2014, 32, 189-201. [CrossRef]

38. Davis, K. A Method to Measure Success Dimensions Relating to Individual Stakeholder Groups. Int. J. Proj. Manag. 2016, 34, 480-493. [CrossRef]

39. Davis, K. An Empirical Investigation into Different Stakeholder Groups Perception of Project Success. Int. J. Proj. Manag. 2017, 35, 604-617. [CrossRef]

40. Tchumtcha Wembe, P. Managing Stakeholders in Engineering Procurement Construction Management Projects in Africa by Chinese Project Managers. Int. J. Constr. Manag. 2020, 1-19. [CrossRef]

41. Saad, A.; Zahid, S.M.; Muhammad, U.B. Role of Awareness in Strengthening the Relationship between Stakeholder Management and Project Success in the Construction Industry of Pakistan. Int. J. Constr. Manag. 2020, 1-10. [CrossRef]

42. Nguyen, T.H.D.; Chileshe, N.; Rameezdeen, R.; Wood, A. Stakeholder Influence Pathways in Construction Projects: Multicase Study. J. Constr. Eng. Manag. 2019, 145, 05019011. [CrossRef]

43. Curran, M.; Spillane, J.P. External Stakeholder Management and Engagement on Urban Construction Projects in Ireland. Proc. Inst. Civ. Eng. Manag. Procure. Law 2020, 174, 59-68. [CrossRef]

44. Wateridge, J. How Can IS/IT Projects Be Measured for Success? Int. J. Proj. Manag. 1998, 16, 59-63. [CrossRef]

45. Koutsikouri, D.; Austin, S.; Dainty, A. Critical Success Factors in Collaborative Multi-Disciplinary Design Projects. J. Eng. Des. Technol. 2008, 6, 198-226. [CrossRef]

46. Müller, R.; Jugdev, K. Critical Success Factors in Projects. Int. J. Manag. Proj. Bus. 2012, 5, 757-775. [CrossRef]

47. Rohman, M.A.; Doloi, H.; Heywood, C.A. Success Criteria of Toll Road Projects from a Community Societal Perspective. Built Environ. Proj. Asset Manag. 2017, 7, 32-44. [CrossRef]

48. Ameyaw, E.E.; Chan, A.P.C. Critical Success Factors for Public-Private Partnership in Water Supply Projects. Facilities 2016, 34, 124-160. [CrossRef]

49. Meng, X.; Zhao, Q.; Shen, Q. Critical Success Factors for Transfer-Operate-Transfer Urban Water Supply Projects in China. J. Manag. Eng. 2011, 27, 243-251. [CrossRef]

50. Gunathilaka, S.; Tuuli, M.M.; Dainty, A.R.J. Critical Analysis of Research on Project Success in Construction Management Journals. In Proceedings of the 29th Annual Association of Researchers in Construction Management Conference, ARCOM, Reading, UK, 2-4 September 2013; pp. 979-988.

51. Shenhar, A.J.; Dvir, D.; Levy, O.; Maltz, A.C. Project Success: A Multidimensional Strategic Concept. Long Range Plan. 2001, 34, 699-725. [CrossRef]

52. Pinto, J.K.; Prescott, J.E. Variations in Critical Success Factors over the Stages in the Project Life Cycle. J. Manag. 1988, $14,5$. [CrossRef]

53. Chan, A.P.C.; Scott, D.; Lam, E.W.M. Framework of Success Criteria for Design/Build Projects. J. Manag. Eng. 2002, 18, 120-128. [CrossRef]

54. Jugdev, K.; Müller, R. A Retrospective Look at Our Evolving Understanding of Project Success. Proj. Manag. J. 2005, 36, 19-31. [CrossRef]

55. Baker, B.N.; Murphy, D.C.; Fisher, D. Factors Affecting Project Success. In Project Management Handbook, 2nd ed.; Cleland, D.I., King, W.R., Eds.; Wiley: Hoboken, NJ, USA, 1988; pp. 902-919. 
56. Dvir, D.; Raz, T.; Shenhar, A.J. An Empirical Analysis of the Relationship between Project Planning and Project Success. Int. J. Proj. Manag. 2003, 21, 89-95. [CrossRef]

57. Shenhar, A.J. Levy, O.D.D. Mapping the Dimensions of Project Success. Proj. Manag. J. 1997, 28, 5-13.

58. Lipovetsky, S.; Tishler, A.; Dvir, D.; Shenhar, A.J. The Relative Importance of Success Dimensions in Defense Development Projects. RD Manag. 1997, 27, 97-106.

59. Pinto, J.K.; Mantel, S.J. The Causes of Project Failure. IEEE Trans. Eng. Manag. 1990, 37, 269-276. [CrossRef]

60. Fortune, J.; White, D. Framing of Project Critical Success Factors by a Systems Model. Int. J. Proj. Manag. 2006, $24,53-65$. [CrossRef]

61. Fraczkowski, K. Gładysz, B., Kuchta. D. Analysis of Factors Affecting the Success of IT Projects in Poland; Reports of the Institute of Organization and Management; Wrocław University of Science and Technology: Wrocław, Poland, 2014; p. 39.

62. Kiani Mavi, R.; Standing, C. Critical Success Factors of Sustainable Project Management in Construction: A Fuzzy DEMATEL-ANP Approach. J. Clean. Prod. 2018, 194, 751-765. [CrossRef]

63. Joia, L.A.; Melon, M. The Social Representation of Success in IT Projects. Int. J. Manag. Proj. Bus. 2020, 13, 1578-1599. [CrossRef]

64. Vujović, V.; Denić, N.; Stevanović, V.; Stevanović, M.; Stojanović, J.; Cao, Y.; Alhammadi, Y.; Jermsittiparsert, K.; Van Le, H.; Wakil, K.; et al. Project Planning and Risk Management as a Success Factor for IT Projects in Agricultural Schools in Serbia. Technol. Soc. 2020, 63, 101371. [CrossRef]

65. Yong, Y.C.; Mustaffa, N.E. Critical Success Factors for Malaysian Construction Projects: An Empirical Assessment. Constr. Manag. Econ. 2013, 31, 959-978. [CrossRef]

66. Doloi, H. Cost Overruns and Failure in Project Management: Understanding the Roles of Key Stakeholders in Construction Projects. J. Constr. Eng. Manag. 2013, 139, 267-279. [CrossRef]

67. Nguyen, T.P.; Chileshe, N. Revisiting the Critical Factors Causing Failure of Construction Projects in Vietnam. In Proceedings of the 29th Annual Association of Researchers in Construction Management Conference, ARCOM, Reading, UK, 2-4 September 2013; pp. 929-938.

68. Yang, J.; Shen, G.Q.; Ho, M.; Drew, D.S.; Chan, A.P.C. Exploring Critical Success Factors for Stakeholder Management in Construction Projects. J. Civ. Eng. Manag. 2009, 15, 337-348. [CrossRef]

69. Toor, S.-u.-R.; Ogunlana, S.O. Critical COMs of Success in Large-Scale Construction Projects: Evidence from Thailand Construction Industry. Int. J. Proj. Manag. 2008, 26, 420-430. [CrossRef]

70. Pirotti, A.; Keshavarzsaleh, A.; Rahim, F.A.M.; Zakaria, N. Effective Factors on Project Success in Malaysian Construction Industry. J. Eng. Proj. Prod. Manag. 2020, 10,1-10. [CrossRef]

71. Dixit, S. Study of Factors Affecting the Performance of Construction Projects in AEC Industry. Organ. Technol. Manag. Constr. 2020, 12, 2275-2282. [CrossRef]

72. Pham, V.Q.; Nguyen, B.K.Q.; Van Tu, B.; Pham, H.T.T.; Le, T.Q. Critical Success Factors of Project Management: The Case of Construction Related Projects in Vietnam. J. Asian Financ. Econ. Bus. 2019, 6, 223-230. [CrossRef]

73. Kuwaiti, E.A.; Ajmal, M.M.; Hussain, M. Determining Success Factors in Abu Dhabi Health Care Construction Projects: Customer and Contractor Perspectives. Int. J. Constr. Manag. 2018, 18, 430-445. [CrossRef]

74. Surlan, N.; Cekic, Z.; Torbica, Z. Use of Value Management Workshops and Critical Success Factors in Introducing Local Experience on the International Construction Projects. J. Civ. Eng. Manag. 2016, 22, 1021-1031. [CrossRef]

75. Gudiene, N.; Banaitis, A.; Podvezko, V.; Banaitiene, N. Identification and Evaluation of the Critical Success Factors for Construction Projects in Lithuania: AHP Approach. J. Civ. Eng. Manag. 2014, 20, 350-359. [CrossRef]

76. Yong, Y.C.; Mustaffa, N.E. Analysis of Factors Critical to Construction Project Success in Malaysia. Eng. Constr. Archit. Manag. 2012, 19, 543-556. [CrossRef]

77. Chen, Y.Q.; Zhang, Y.B.; Liu, J.Y.; Mo, P. Interrelationships among Critical Success Factors of Construction Projects Based on the Structural Equation Model. J. Manag. Eng. 2012, 28, 243-251. [CrossRef]

78. Ahadzie, D.K.; Proverbs, D.G.; Olomolaiye, P.O. Critical Success Criteria for Mass House Building Projects in Developing Countries. Int. J. Proj. Manag. 2008, 26, 675-687. [CrossRef]

79. Lam, E.W.M.; Chan, A.P.C.; Chan, D.W.M. Determinants of Successful Design-Build Projects. J. Constr. Eng. Manag. 2008, 134, 333-341. [CrossRef]

80. Yu, A.T.W.; Shen, Q.; Kelly, J.; Hunter, K. Investigation of Critical Success Factors in Construction Project Briefing by Way of Content Analysis. J. Constr. Eng. Manag. 2006, 132, 1178-1186. [CrossRef]

81. Li, B.; Akintoye, A.; Edwards, P.J.; Hardcastle, C. Critical Success Factors for PPP/PFI Projects in the UK Construction Industry. Constr. Manag. Econ. 2005, 23, 459-471. [CrossRef]

82. Chan, A.P.C.; Scott, D.; Chan, A.P.L. Factors Affecting the Success of a Construction Project. J. Constr. Eng. Manag. 2004, 130, 153-155. [CrossRef]

83. Parfitt, M.K.; Sanvido, V.E. Checklist of Critical Success Factors for Building Projects. J. Manag. Eng. 1993, 9, 243-249. [CrossRef]

84. Cho, Y.; Yoon, S.-P.; Kim, K.-S. An Industrial Technology Roadmap for Supporting Public R\&D Planning. Technol. Forecast. Soc. Change 2016, 107, 1-12. [CrossRef]

85. Toljaga-Nikolić, D.; Todorović, M.; Dobrota, M.; Obradović, T.; Obradović, V. Project Management and Sustainability: Playing Trick or Treat with the Planet. Sustainability 2020, 12, 8619. [CrossRef] 
86. Aarseth, W.; Ahola, T.; Aaltonen, K.; Økland, A.; Andersen, B. Project Sustainability Strategies: A Systematic Literature Review. Int. J. Proj. Manag. 2017, 35, 1071-1083. [CrossRef]

87. Chawla, V.K.; Chanda, A.K.; Angra, S.; Chawla, G.R. The Sustainable Project Management: A Review and Future Possibilities. J. Proj. Manag. 2018, 3, 157-170. [CrossRef]

88. Goedknegt, D.; Silvius, A.J.G. He Implementation of Sustainability Principles in Project Management. In Proceedings of the 26th IPMA World Congress, Crete, Greece, 29-31 October 2012; pp. 875-882.

89. Labelle, F.; Leyrie, C. "Stakepartner Management" in Projects: A Turn-of-the-Century Turnaround at Alcan. J. Mod. Proj. Manag. 2013, 1, 33-43.

90. AlWaer, H.; Sibley, M.; Lewis, J. Different Stakeholder Perceptions of Sustainability Assessment. Archit. Sci. Rev. 2008, 51, 48-59. [CrossRef]

91. Bal, M.; Bryde, D.; Fearon, D.; Ochieng, E. Stakeholder Engagement: Achieving Sustainability in the Construction Sector. Sustainability 2013, 5, 695-710. [CrossRef]

92. International Organization for Standardization. ISO 26000: 2010 Guidance on Social Responsibility. 2010. Available online: https: / / standards.iteh.ai/catalog/standards/iso/3b961c39-fd40-41bd-bd95-dda0b44308a9/iso-26000-2010 (accessed on 1 June 2021).

93. Silvius, A.J.G.; Schipper, R. A Conceptual Model for Exploring the Relationship Between Sustainability and Project Success. Procedia Comput. Sci. 2015, 64, 334-342. [CrossRef]

94. Martens, M.L.; Carvalho, M.M. Sustainability and Success Variables in the Project Management Context: An Expert Panel. Proj. Manag. J. 2016, 47, 24-43. [CrossRef]

95. Yazici, H.J. An Exploratory Analysis of the Project Management and Corporate Sustainability Capabilities for Organizational Success. Int. J. Manag. Proj. Bus. 2020, 13, 793-817. [CrossRef]

96. Khalifeh, A.; Farrell, P.; Al-edenat, M. The Impact of Project Sustainability Management (PSM) on Project Success: A Systematic Literature Review. J. Manag. Dev. 2020, 39, 453-474. [CrossRef]

97. Fuentes-Ardeo, L.; Otegi-Olaso, J.R.; Aguilar-Fernandez, M.E. How the Project Knowledge Management and the Sustainability in Project Management Affect the Project Success. In Proceedings of the 2017 IEEE 9th International Conference on Intelligent Data Acquisition and Advanced Computing Systems: Technology and Applications, IDAACS 2017, Bucharest, Romania, 21-23 September 2017; Volume 2, pp. 884-887. [CrossRef]

98. Dubois, O.; Silvius, G. The Relation between Sustainable Project Management and Project Success. Int. J. Manag. Sustain. 2020, 9 , 218-238. [CrossRef]

99. Carvalho, M.M.; Rabechini, R. Can Project Sustainability Management Impact Project Success? An Empirical Study Applying a Contingent Approach. Int. J. Proj. Manag. 2017, 35, 1120-1132. [CrossRef]

100. Martens, M.L.; Carvalho, M.M. Key Factors of Sustainability in Project Management Context: A Survey Exploring the Project Managers' Perspective. Int. J. Proj. Manag. 2017, 35, 1084-1102. [CrossRef]

101. Stanitsas, M.; Kirytopoulos, K.; Leopoulos, V. Integrating Sustainability Indicators into Project Management: The Case of Construction Industry. J. Clean. Prod. 2021, 279, 123774. [CrossRef]

102. Amadi, C.; Carrillo, P.; Tuuli, M. PPP Projects: Improvements in Stakeholder Management. Eng. Constr. Archit. Manag. 2020, 27, 544-560. [CrossRef]

103. Yang, R.J.; Jayasuriya, S.; Gunarathna, C.; Arashpour, M.; Xue, X.; Zhang, G. The Evolution of Stakeholder Management Practices in Australian Mega Construction Projects. Eng. Constr. Archit. Manag. 2018, 25, 690-706. [CrossRef]

104. Mok, K.Y.; Shen, G.Q.; Yang, J. Stakeholder Management Studies in Mega Construction Projects: A Review and Future Directions. Int. J. Proj. Manag. 2015, 33, 446-457. [CrossRef]

105. Singh, S.; Chinyio, E.; Suresh, S. The Implementation of Stakeholder Management and Building Information Modelling (BIM) in UK Construction Projects. In Proceeding of the 34th Annual ARCOM Conference, ARCOM, Belfast, UK, 3-5 September 2018; pp. 766-775.

106. Park, H.; Kim, K.; Kim, Y.-W.; Kim, H. Stakeholder Management in Long-Term Complex Megaconstruction Projects: The Saemangeum Project. J. Manag. Eng. 2017, 33, 05017002. [CrossRef]

107. Yang, R.J.; Shen, G.Q.P. Framework for Stakeholder Management in Construction Projects. J. Manag. Eng. 2015, $31,04014064$. [CrossRef]

108. Storvang, P.; Clarke, A.H. How to Create a Space for Stakeholders' Involvement in Construction. Constr. Manag. Econ. 2014, 32, 1166-1182. [CrossRef]

109. Gan, X.; Guo, L. A Framework for Stakeholder Analysis in Construction Projects. In WIT Transactions on Information and Communication Technologies; WIT Press: Southampton, UK, 2014; Volume 61, pp. 1869-1876. [CrossRef]

110. Hartmann, A.; Hietbrink, M. An Exploratory Study on the Relationship between Stakeholder Expectations, Experiences and Satisfaction in Road Maintenance. Constr. Manag. Econ. 2013, 31, 345-358. [CrossRef]

111. Olander, S. Stakeholder Impact Analysis in Construction Project Management. Constr. Manag. Econ. 2007, 25, 277-287. [CrossRef]

112. Olander, S.; Landin, A. Evaluation of Stakeholder Influence in the Implementation of Construction Projects. Int. J. Proj. Manag. 2005, 23, 321-328. [CrossRef]

113. Xue, J.; Shen, G.Q.; Yang, R.J.; Wu, H.; Li, X.; Lin, X.; Xue, F. Mapping the Knowledge Domain of Stakeholder Perspective Studies in Construction Projects: A Bibliometric Approach. Int. J. Proj. Manag. 2020, 38, 313-326. [CrossRef] 
114. Mosey, D. Early Contractor Involvement in Building Procurement: Contracts, Partnering and Project Management; Wiley-Blackwell: New York, NY, USA, 2009.

115. Sepasi, S.; Rexhepi, G.; Rahdari, A. The changing prospects of corporate social responsibility in the decade of action: Do personal values matter? Corp. Soc. Responsib. Environ. Manag. 2021, 28, 138-152. [CrossRef]

116. Sepasi, S.; Rahdari, A.; Rexhepi, G. Developing a sustainability reporting assessment tool for higher education institutions: The University of California. Sustain. Dev. 2018, 26, 672-682. [CrossRef]

117. Sońta-Drączkowska, E. Wptyw Zarządzania Projektami Na Tworzenie Wartości Przedsiębiorstwa; SGH Warsaw School of Economics: Warszawa, Poland, 2007. 